\title{
Air Pollution in New Delhi during Late Winter: An Overview of a Group of Campaign Studies Focusing on Composition and Sources
}

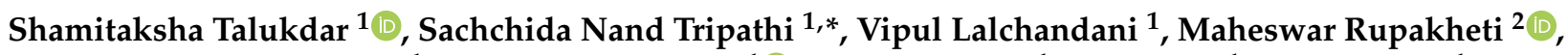 \\ Himadri Sekhar Bhowmik ${ }^{1}$, Ashutosh K. Shukla ${ }^{1}{ }^{1}$, Vishnu Murari ${ }^{1}$, Ravi Sahu ${ }^{1}$, Vaishali Jain ${ }^{1}$, Nidhi Tripathi ${ }^{3}$, \\ Jay Dave ${ }^{4}$, Neeraj Rastogi ${ }^{4}$ (D) and Lokesh Sahu ${ }^{3}$ \\ 1 Department of Civil Engineering, Indian Institute of Technology Kanpur, Kanpur 208016, India; \\ shamit@iitk.ac.in (S.T.); vipullc@iitk.ac.in (V.L.); himadrib@iitk.ac.in (H.S.B.); akumars@iitk.ac.in (A.K.S.); \\ mvishnu@iitk.ac.in (V.M.); ravisahu@iitk.ac.in (R.S.); jainv@iitk.ac.in (V.J.) \\ 2 Institute for Advanced Sustainability Studies, 14467 Potsdam, Germany; Maheswar.Rupakheti@iass-potsdam.de \\ 3 Physical Research Laboratory, Space and Atmospheric Sciences Division, Ahmedabad 380009, India; \\ nidhi@prl.res.in (N.T.); lokesh@prl.res.in (L.S.) \\ 4 Physical Research Laboratory, Geosciences Division, Ahmedabad 380009, India; jaydave32@gmail.com (J.D.) \\ neeraj6676@gmail.com (N.R.) \\ * Correspondence: snt@iitk.ac.in
}

\section{check for} updates

Citation: Talukdar, S.; Tripathi, S.N.; Lalchandani, V.; Rupakheti, M.;

Bhowmik, H.S.; Shukla, A.K.; Murari, V.; Sahu, R.; Jain, V.; Tripathi, N.; et al. Air Pollution in New Delhi during Late Winter: An Overview of a Group of Campaign Studies Focusing on Composition and Sources. Atmosphere 2021, 12, 1432. https://doi.org/ $10.3390 /$ atmos 12111432

Academic Editor: Pascal Flament

Received: 21 August 2021

Accepted: 25 October 2021

Published: 29 October 202

Publisher's Note: MDPI stays neutral with regard to jurisdictional claims in published maps and institutional affiliations.

Copyright: (c) 2021 by the authors. Licensee MDPI, Basel, Switzerland. This article is an open access article distributed under the terms and conditions of the Creative Commons Attribution (CC BY) license (https:/ / creativecommons.org/licenses/by/ $4.0 /)$.

\begin{abstract}
In recent times, a significant number of studies on the composition and sources of fine particulate matters and volatile organic compounds have been carried out over Delhi, either initiated by or in association with the researchers from the Indian Institute of Technology Kanpur (IIT Kanpur), in collaboration with researchers from within and outside India. All these studies utilized highly time-resolved, campaign-mode observations made with state-of-the-art instrumentation during the late winter months (mid-January to March) of 2018. Individually, each of these studies were rigorous in nature, containing explicit detailing about different types of ambient air pollutants in Delhi such as organic aerosols, inorganic elements, metals, carbonaceous aerosols, and volatile organic compounds. This study consolidates the extremely useful knowledge on source attribution of these air pollutants in the Delhi National Capital Region currently contained in these fragmented studies, which is vital to further enhancing our understanding of composition, characteristics, and sources of air pollutants over Delhi, as well as to designing appropriate mitigation measures tailored to local specifics.
\end{abstract}

Keywords: Delhi NCR; $\mathrm{PM}_{2.5}$; VOCs; source apportionment; consolidating fragmented studies; evidence for policy

\section{Introduction}

Delhi, the capital of India, experiences extreme level of air pollution. In a recent study [1] it was reported that the $\mathrm{PM}_{2.5}$ level in Delhi exceeded the Indian National Ambient Air Quality Standards (NAAQs) on 200 days in a year. Especially in winter, the pollution level being coupled with the dynamics of the shallow planetary boundary layer (PBL), the situation becomes worse than other seasons [2]. It has been reported that the adverse health impact of ambient air pollution (due to both $\mathrm{PM}_{2.5}$ and $\mathrm{PM}_{10}$ ) has taken around 1.7 million lives in India every year on average since 1990 [3,4], and this makes it utterly important to measure and monitor particulate matters of all sizes. Recent studies revealed that $\mathrm{PM}_{2.5}$ can be a potential parameter to promote the transmission of COVID-19 [5,6]. However, it has been mentioned that the role of air pollution in the COVID-19 pandemic needs further analysis to assess whether aerosols are able to carry the virus, or the higher concentration of pollutant aerosol only turns mild cases into severe [6]. Studies from the last two decades reported consistent high concentration of fine particulate pollutant in Delhi. Srivastava et al. using 2005-2006 wintertime measurements, reported that the mean concentration of fine mode particulates in Delhi was $183 \pm 26.9 \mu \mathrm{g} \mathrm{m}^{-3}$ [7]. A similar observation reported by Tiwari et al. found the 
concentrations of $\mathrm{PM}_{2.5}$ (aggregate mass of particles with aerodynamic diameter $\leq 2.5 \mu \mathrm{m}$ ) in winter (from December 2011-March 2012) were $186.5 \pm 149.7 \mu \mathrm{g} \mathrm{m}^{-3}$, which is much higher than the Indian NAAQ's limit of $40 \mu \mathrm{g} \mathrm{m}^{-3}$ for annual $\mathrm{PM}_{2.5}$ concentration [8]. Although these studies performed source apportionment, they could reveal only few major sources such as vehicular emission, coal combustion, and crustal dust [7,8]. Pant et al. in 2015, reported an average $\mathrm{PM}_{2.5}$ concentration during winter (15 December 2013 to 15 January 2014) of $276.9 \pm 99.9 \mathrm{\mu g} \mathrm{m}^{-3}$ [2]. Sharma et al. in 2016, reported, using observations from January 2013 to December 2014, that the average mass concentration of $\mathrm{PM}_{2.5}$ during winter months was $216 \pm 93.2 \mu \mathrm{g} \mathrm{m}^{-3}$ (with $22.3 \%$ of $\mathrm{PM}_{2.5}$ composed of major and trace elements); and using the PMF (positive matrix factorization) model, major sources of $\mathrm{PM}_{2.5}$ were determined as secondary aerosols $(21.3 \%)$, followed by soil dust (20.5\%), vehicle emissions $(19.7 \%)$, biomass burning (14.3\%), fossil fuel combustion (13.7\%), industrial emissions (6.2\%), and sea salt (4.3\%) [9]. More precise determination of the composition and sources of pollutants in the atmosphere of Delhi National Capital Region (NCR) have become utterly necessary day by day, for mitigation purposes and due to several other policymaking issues. In recent times (mostly in 2018), a group of rigorous studies was carried out based on campaign observations (both in online and offline modes) over Delhi, either initiated by or conducted in association with the air quality researchers of the Indian Institute of Technology Kanpur (IIT), in collaboration with researchers from national and international institutes. The common period in all these studies was between mid-January andmid-March of 2018, which is considered the late winter period. Most importantly, all these studies investigated the chemical composition and source apportionment of fine particulate matter, carbonaceous aerosols, elements in aerosols, and gaseous volatile organic compounds (VOCs) [10-15]. More specifically, Tobler et al. and Lalchandani et al. studied the highly time-resolved chemical characterization of fine particulate matter and source apportionment of organic aerosols and black carbon [10,11]. Rai et al. worked on the quantification, chemical composition, and source apportionment of highly time-resolved elements in $\mathrm{PM}_{10}$ and $\mathrm{PM}_{2.5}$ (with an aggregate mass of particles with aerodynamic diameter less or equal to $10 \mu \mathrm{m}$ and $2.5 \mu \mathrm{m}$, respectively) [12]. Temporal and spatial variability of carbonaceous species in $\mathrm{PM}_{2.5}$ was studied by Bhowmik et al. using filter sampling at five sites on the Indo-Gangetic Plain (IGP) and their offline analysis [14]; and very recently, characteristics and sources of light-absorbing fine particulates were examined by Singh et al. [15]. Rastogi et al., in 2021 , reported on the diurnal variability in the entire spectra (300 to $600 \mathrm{~nm}$ ) of watersoluble brown carbon (WS-BrC), which revealed many interesting features of WS-BrC [16]. Wang et al. investigated the characteristics and sources of VOCs [13]. Puthussery et al. conducted a study on the measurements of the oxidative potential of $\mathrm{PM}_{2.5}$ to link the aerosol exposure to its adverse health effects [17]. Regarding the need for these hours of research, the aforementioned studies have contributed to a very crucial dimension of investigation, analysis, and assessment of Delhi's air quality. Singh et al. and Puthussery et al. conducted their study in 2019, but in the rest of the studies, the common period of sampling/measurements was the late winter months (mid-January to mid-March) of 2018. These extensive research works individually presented exclusive details about different types of air pollutants in Delhi. Now, the purpose of this study is to provide an overview of all these fragmented studies in order to give a comprehensive synthesis about their important findings. This can increase the applicability of these fragmented studies and will help reduce the knowledge gaps, supporting the design of future studies as well as policy developments. Within this framework, the discussions in the following sections will focus on the components of fine pollutant particulate matter and VOCs, and their measurement and source apportionment precisely.

\section{Sites and Instruments Used in Past Studies}

In this section, a brief description of the instruments that have been used in the aforementioned group of studies is presented. The set of instruments used in these studies make it possible to perform collocated monitoring of a broad range of chemical compounds 
present in aerosols in the atmosphere, including nonrefractory particulate matters (NR $\mathrm{PM}_{2.5}$ ), $\mathrm{BC}$, major ions, metals, and VOCs, both in online and offline mode. This group of studies presented the measurements of the individual parameters and described the corresponding instrument details in the respective papers. The sampling sites in Delhi for these studies were the Indian Institute of Technology Delhi (IITDelhi) $\left(28.54^{\circ} \mathrm{N}, 77.19^{\circ} \mathrm{E}\right)$ and the Indian Institute of Tropical Meteorology Delhi (IITMDelhi) $\left(28.62^{\circ} \mathrm{N}, 77.17^{\circ} \mathrm{E}\right)$, as well as a third site located at Faridabad, Haryana, around $40 \mathrm{~km}$ northwest of New Delhi, the Manav Rachna International Institute of Research and Studies (MRIIRS) (28.45 ${ }^{\circ} \mathrm{N}$, $77.28^{\circ} \mathrm{E}$ ). To investigate the evolution of $\mathrm{PM}_{2.5}$ concentration and composition with high time resolution in New Delhi, Tobler et al., used a time-of-flight aerosol chemical speciation monitor (ToF-ACSM) (Aerodyne Research Inc., Billerica, MA, USA) [11,18] and an aethalometer (Magee Scientific, model AE-33). Lalchandani et al. used a high-resolution long-time-of-flight aerosol mass spectrometer (L-ToF-AMS) equipped with a $\mathrm{PM}_{2.5}$ aerodynamic lens (Aerodyne Research Inc., Billerica, MA, USA) at the IITDelhi site; a ToF-ACSM at the IITMDelhi site; and a high-resolution time-of-flight aerosol mass spectrometer (HR-ToFAMS) at the MRIIRS site. An aethalometer (AE-33) and a single-particle soot photometer (SP2) were also used in their study for the measurement of BC aerosol [10]. An Xact $625 \mathrm{i}^{\circledR}$ Ambient Metals Monitor (Cooper Environmental Services, Tigard, ON, USA) was used by Rai et al. [12] at the IITDelhi site, and Wang et al. used a proton-transfer-reaction time-of-flight mass spectrometer (PTR-ToF-MS 8000) (Ionicon Analytical GmbH, Innsbruck, Austria) to measure gaseous VOCs at IITDelhi and MRIIRS [13]. On the other hand, for the offline analysis at IITDelhi site, a high-volume sampler (HVS) was used to collect $\mathrm{PM}_{2.5}$ samples on quartz filter media. The post-sampling offline analysis was carried out for elemental carbon (EC) and organic carbon (OC) using an EC-OC analyzer, for water-soluble organic carbon (WSOC) using TOC-L analyzer, for major anions and cations using an ion chromatograph (IC), and for and heavy and trace metals using inductively coupled plasma mass spectroscopy (ICP-MS). Moreover, a real-time oxidative potential (OP) instrument to measure health-related metrics was introduced in the study by Puthussery et al. at the IITDelhi site [17]. In this section, the instruments are very briefly described; elaborate discussions of individual instruments are available in the corresponding papers as cited. The information on the instruments for measuring different pollutant parameters at different sites are presented in Table 1, followed by short details in the text.

\subsection{High-Resolution Time-of-Flight Aerosol Mass Spectrometer (HR-ToF-AMS)}

The HR-ToF-AMS is used to measure size-resolved mass spectra of the nonrefractory (NR) fraction of either $\mathrm{PM}_{1}$ or $\mathrm{PM}_{2.5}$ (respectively denoted as $\mathrm{NR}-\mathrm{PM}_{1}$ and $\mathrm{NR}-\mathrm{PM}_{2.5}$ ), depending on the installed inlet and aerodynamic lens. The detailed working principles of the HR-ToF-AMS were described by DeCarlo et al. [19]. In brief, aerosol particles are sampled through a $100 \mu \mathrm{m}$ diameter critical orifice, and particles entering the aerodynamic lens system are focused into a narrow beam. A combination of inlet and aerodynamic lens systems allows particles of vacuum aerodynamic diameter less than 1 or $2.5 \mu \mathrm{m}$ [19]. The focused particle beam approaches the sizing chamber, where the particle size is determined by measuring the time taken by the particle to travel the fixed length of the sizing chamber. The particle beam then impacts a vaporizer heated at $600{ }^{\circ} \mathrm{C}$, which evaporates the nonrefractory particles. The resulting gas molecules are ionized by electron ionization at $70 \mathrm{eV}$, and the ions formed are detected by a time-of-flight mass spectrometer according to their mass-to-charge ratio $(\mathrm{m} / \mathrm{z})$. An L-ToF-AMS has similar working principles and operation as an HR-ToF-AMS, but with an approximately twofold length of the mass spectrometer compared to an HR-ToF-AMS, enabling it provide twice the mass resolution that an HR-ToF-AMS provides in V-mode. 
Table 1. The information on the instruments used for measuring different pollutant parameters at different sites (the details are in the main text).

\begin{tabular}{|c|c|c|c|c|}
\hline Instruments & $\begin{array}{l}\text { Site of Sample } \\
\text { Collection }\end{array}$ & Sampling Period & Type of Samples and Volume & Parameters \\
\hline $\begin{array}{l}\text { High-resolution time-of-flight aerosol mass } \\
\text { spectrometer (HR-ToF-AMS) }\end{array}$ & $\begin{array}{l}\text { MRIIRS } \\
\text { Faridabad } \\
\text { IITDelhi }\end{array}$ & $\begin{array}{l}27 \text { January-15 March } 2018 \\
17-19 \text { January } 2018 \text { and } \\
5 \text { February-11 March } 2018\end{array}$ & Ambient air $0.0 .08 \mathrm{~L} / \mathrm{min}$ & $\begin{array}{l}\text { Real-time nonrefractory and size-resolved } \\
\qquad \mathrm{PM}_{2.5} \text { speciation }\end{array}$ \\
\hline $\begin{array}{l}\text { Time-of-flight aerosol chemical speciation } \\
\text { monitor (ToF-ACSM) }\end{array}$ & IITMDelhi & 17 February-15 March 2018 & ambient air $(0.1 \mathrm{~L} / \mathrm{min})$ & Real-time bulk nonrefractory $\mathrm{PM}_{2.5}$ speciation \\
\hline $\begin{array}{l}\text { Proton-transfer-reaction time-of-flight mass } \\
\text { spectrometer (PTR-ToF-MS) }\end{array}$ & $\begin{array}{l}\text { IITDelhi } \\
\text { MRIIRS } \\
\text { Faridabad }\end{array}$ & $\begin{array}{l}18 \text { January-10 March } 2018 \\
16 \text { January-8 March } 2018\end{array}$ & ambient air $(0.06 \mathrm{~L} / \mathrm{min})$ & $\begin{array}{l}\text { High time- and mass-resolved online } \\
\text { measurements of volatile organic compounds }\end{array}$ \\
\hline Aethalometer (AE 33) & $\begin{array}{l}\text { IITDelhi } \\
\text { IITMDelhi }\end{array}$ & $\begin{array}{c}\text { 17-19 January } 2018 \\
\text { and } 5 \text { February-11 March } 2018 \\
17 \text { February-15 March } 2018\end{array}$ & $\begin{array}{c}\text { Ambient air } \\
\text { sampled } \\
\text { on a quartz filter tape } \\
(3 \mathrm{~L} / \mathrm{min})\end{array}$ & Black carbon mass concentration \\
\hline PILS-LWCC-TOC analyzer & IITDelhi & 9 January-3 March 2018 & $\begin{array}{l}\text { PILS liquid, } \\
\text { sample flow rate }(0.7 \mathrm{~mL} / \mathrm{min}) \\
\text { and air sampling flow rate } \\
(16.7 \mathrm{~L} / \mathrm{min})\end{array}$ & $\begin{array}{l}\text { Ambient aerosol } \\
\text { extracts at wavelengths ranging from } 300 \text { to } \\
600 \mathrm{~nm} \text { and water-soluble } \mathrm{BrC}\end{array}$ \\
\hline Single-particle soot photometer (SP2) & $\begin{array}{l}\text { MRIIRS } \\
\text { Faridabad }\end{array}$ & 27 January-15 March 2018 & Ambient air & $\begin{array}{c}\text { Black carbon }(\mathrm{BC}) \text { mass concentration, } \mathrm{BC} \\
\text { number concentration, } \mathrm{BC} \text { size distribution, } \mathrm{BC} \\
\text { mixing state }\end{array}$ \\
\hline Xact $625 \mathrm{i}^{\circledR}$ ambient metals monitor & IITDelhi & $\begin{array}{l}20 \text { January-11 March in } 2018 \\
15 \text { January-9 February } 2019\end{array}$ & $\begin{array}{l}\text { Ambient air } \\
\text { Sampled } \\
\text { on Teflon filter tape } \\
(16.7 \mathrm{~L} / \mathrm{min})\end{array}$ & $\begin{array}{l}\text { Equipped to report the following } \\
44 \text { elements-Al, } \mathrm{Si}, \mathrm{P}, \mathrm{S}, \mathrm{Cl}, \mathrm{K}, \mathrm{Ca}, \mathrm{Ti}, \mathrm{V}, \mathrm{Cr}, \mathrm{Mn} \text {, } \\
\mathrm{Fe}, \mathrm{Co}, \mathrm{Ni}, \mathrm{Cu}, \mathrm{Zn}, \mathrm{Ga}, \mathrm{Ge}, \mathrm{As}, \mathrm{Se}, \mathrm{Br}, \mathrm{Rb}, \mathrm{Sr}, \mathrm{Y}, \mathrm{Zr} \text {, } \\
\text { Mo, } \mathrm{Pd}, \mathrm{Ag}, \mathrm{Cd}, \mathrm{In}, \mathrm{Sn}, \mathrm{Sb}, \mathrm{Te}, \mathrm{Cs}, \mathrm{Ba}, \mathrm{La}, \mathrm{Ce}, \mathrm{W} \text {, } \\
\mathrm{Pt}, \mathrm{Au}, \mathrm{Hg}, \mathrm{Tl}, \mathrm{Pb} \text {, and Bi }\end{array}$ \\
\hline High-volume sampler & IITDelhi & January-December 2018 & $\begin{array}{c}\text { Ambient air } \\
\text { sampled on quartz filter media }\end{array}$ & $\mathrm{PM}_{2.5}$ \\
\hline $\begin{array}{l}\text { EC-OC analyzer, TOC-L analyzer and ion } \\
\text { chromatography, inductively coupled plasma } \\
\text { mass spectroscopy (ICP-MS) }\end{array}$ & $\begin{array}{l}\text { IITDelhi } \\
\text { IITMDelhi } \\
\text { MRIIRS } \\
\text { Faridabad }\end{array}$ & January-December 2018 & Offline analysis of quartz filter media & $\begin{array}{l}\text { Elemental carbon (EC), organic carbon (OC), and } \\
\text { total organic carbon (TOC), and major anions } \\
\text { and cations }\left(\mathrm{Na}+, \mathrm{K}^{2}, \mathrm{Ca}^{2+}, \mathrm{Cl}^{-} \text {and } \mathrm{SO}_{4}{ }^{2-}\right)\end{array}$ \\
\hline Real-time oxidative potential (OP) instrument & IITDelhi & 3-9 February 2019 & Ambient air & $\begin{array}{l}\text { Measures the ability of particles to consume } \\
\text { antioxidants and estimates the toxicity of } \\
\text { particulate matters }\end{array}$ \\
\hline
\end{tabular}




\subsection{Time-of-Flight Aerosol Chemical Speciation Monitor}

The ToF-ACSM has similar working principles to AMS, except for the capability of measuring the size of the particles. An ACSM measures ambient air and particle-free air generated using a particle filter in the sampling line, alternatively every $20 \mathrm{~s}$, and the difference between the two mass spectra represents the particle mass spectra. A detailed description of the ToF-ACSM can be found in Fröhlich et al. [18].

\subsection{Proton-Transfer-Reaction Time-of-Flight Mass Spectrometer (PTR-ToF-MS)}

Wang et al. used a proton-transfer-reaction time-of-flight mass spectrometer (PTR-ToFMS) to measure VOCs for their study in 2018 [13]. The PTR-ToF-MS measures nonmethane organic gases (NMOG) with a proton affinity higher than water, which is the most common features of VOCs. Data collected in this study included the mixing ratios of VOCs, NOx, and $\mathrm{CO}$, and meteorological parameters. A detailed description of the instrument can be found in Jordan et al. [20].

\subsection{Aethalometer (Model AE-33)}

An aethalometer measures the light attenuation by particles collected on a quartz fiber filter at seven wavelengths $(370,470,520,590,660,880$, and $950 \mathrm{~nm})$ The equivalent black carbon $(\mathrm{eBC})$ concentrations are estimated using the mass absorption cross section (MAC) value of $7.77 \mathrm{~m}^{2} \mathrm{~g}^{-1}$ for the measurement at the $880 \mathrm{~nm}$ wavelength. The aethalometer (AE33) used by Tobler et al. and Lalchandani et al. for their studies at IITDelhi and IITMDelhi was a dual spot aethalometer, which was capable of taking into account and compensating for light attenuation and surface loading effects. Details of the AE33 have been discussed elsewhere [11,21].

\subsection{PILS-LWCC-TOC Analyzer}

Online measurements of $\mathrm{BrC}$ were performed using an assembled system including a particle-into-liquid sampler, a portable UV-visible spectrophotometer with a liquid waveguide capillary cell, and a total carbon analyzer (PILS-LWCC-TOC). This assembled system was capable of measuring the absorption of ambient aerosol extracts at the wavelengths ranging from 300 to $600 \mathrm{~nm}$ with 2 min integration time, and water-soluble organic carbon (WSOC) with 4 min integration time over a polluted megacity, New Delhi. Details of this instrumental setup can be found elsewhere [16].

\subsection{Single-Particle Soot Photometer (SP2)}

A single-particle soot photometer (SP2) measures real-time BC mass concentration in the size range of 70-500 $\mathrm{nm}$. SP2 uses an intracavity Nd:YAG laser beam to intercept the aerosol flow in a perpendicular plane, and heats individual BC particles to their vaporization temperature, resulting in the $\mathrm{BC}$ particle to emitting incandescent light. This is then detected using avalanche photodiodes and is used to estimate BC mass. The working principle and details of SP2 are explained elsewhere [22,23].

\subsection{Xact $625 i^{\circledR}$ Ambient Metals Monitor}

An Xact $625 \mathrm{i}^{\circledR}$ ambient metals monitor (Cooper Environmental Services, Tigard, ON, USA) was used by Rai et al. in their study to measure elemental compositions of ambient aerosols [12]. It is a sampling and analysing, nondestructive, energy dispersive $\mathrm{X}$-ray fluorescence (XRF) spectrometer designed for online, semicontinuous measurements of elements in aerosols. In the Xact, aerosols are sampled on a Teflon filter tape at a flow rate of $16.7 \mathrm{lpm}$. After each sampling interval of $1 \mathrm{~h}$, the tape is moved forward to the analysis area, where the sample is illuminated with X-rays. The resultant excited X-ray fluorescence photons are collected with a silicon drift detector (SDD). During one XRF analysis, the next sample is collected at a clean spot on the filter tape, and then this cycle is repeated. The spectra are then analyzed and calibrated online. The Xact is calibrated using thin film standards for the individual elements. The details of the instrument are described in Rai et al. [12]. 


\subsection{EC-OC Analyzer, TOC-L Analyzer, and Ion Chromatography}

Bhowmik et al. performed offline OC-EC analysis on an EC-OC carbon analyzer (Model 4F, Sunset Laboratory Inc., Hillsborough, NC, USA) following the European Supersites for Atmospheric Aerosol Research (EUSAAR_2) protocol (Karanasiou et al., 2011) over National Institute for Occupational Safety and Health (NIOSH870) and Interagency Monitoring of Protected Visual Environments (IMPROVE_A). Quartz filter papers (Whatman; $8 \times 12$ inches) were used for collecting $\mathrm{PM}_{2.5}$ aerosols [14]. Water extracts from the filters were used for analyzing WSOC and major cations and anions using a TOC-L analyzer (Model SHIMADZU-TOC-L-CPN, Shimadzu Corporation) and an ion chromatograph (Metrohm 883 Basic IC plus for cations and 882 Compact IC plus for anions), respectively. The choice of protocol in OC-EC analysis and amount of water used for extraction can have an effect on the results. Details of the instrumentation and protocols can be found in [14].

\subsection{Real-Time Oxidative Potential (OP) Instrument}

The oxidative potential (OP), a potential health metric of particulate matter, is the ability of particles to consume antioxidants, and estimates the toxicity of particulate matters. To estimate the OP of ambient particulate matter, a dithiothreitol (DTT) assay is one of the commonly used chemical assays. DTT, in the presence of ambient particulate matters, acts as an electron donor and converts oxygen to its superoxide radical, and the rate of oxidation of DTT during this reaction (termed as DTT activity) is considered to be proportional to the amount of redox-active species present in ambient PM. Puthussery et al. performed the first-ever measurements of a health-related metric, oxidative potential (OP), in Delhi using an indigenous online instrument based on the DTT assay. The details of the instrument are provided in the article by Puthussery et al. [17]. In this instrument, $\mathrm{PM}_{2.5}$ is collected by connecting a $\mathrm{PM}_{2.5}$ cyclone inlet (42 lpm flow rate) at the inlet port of a mist chamber (MC) using a copper tube (with an outer diameter of 0.5 in). The MC is kept filled with a predefined volume of water. As air flows through the $\mathrm{MC}$, mist forming inside the chamber continuously washes out the particles collected onto the PTFE filter, forming a $\mathrm{PM}_{2.5}$ suspension in water. After every hour, this $\mathrm{PM}_{2.5}$ suspension is withdrawn and fed into an analytical system. In the analytical component of the automated system, the $\mathrm{PM}_{2.5}$ suspension is mixed with potassium phosphate buffer $(\mathrm{pH} 7.4,0.5 \mu \mathrm{M}$ ) and DTT (final concentration in the reaction vial is $100 \mu \mathrm{M}$ ) and incubated at $37^{\circ} \mathrm{C}$ using a thermomixer (at $400 \mathrm{rpm}$ ). The analytical system measures the decay of DTT with time, based on a spectrophotometric technique, coupled to a miniature online spectrophotometer assembly using dithiobis (2-nitrobenzoic acid), and determines the volume normalized DTT activity in units of nanomoles of DTT consumed per minute per cubic meter of air.

\section{Overview of Groups' Results and Discussion}

\subsection{Types of Fine Pollutants in the Environment of Delhi Megacity}

The group of published studies we will be discussing here have investigated the composition and sources of nonrefractory particulate matter (NR-PM), BC, elements, and VOCs in the New Delhi area using highly time-resolved online measurements, some at a single site (IITDelhi) and others at multiple sites (IITDelhi, IITMDelhi, and MRIIRS). The types of air pollutants reported during the campaign in the Delhi-NCR area by these studies [10-14] in the late winter period of 2018 were categorized mainly as organics, chloride, ammonium, sulfate, nitrate, BC, elements, and VOCs. Lalchandani et al. found during the observation period of mid-January to mid-March at IITD that the mean hourly average of $\mathrm{PM}_{2.5}$ (eq.) concentration (sum of NR-PM 2.5 and $\mathrm{BC}$ ) was $153.8 \pm 109.4 \mathrm{\mu gm}^{-3}$, with a maximum concentration up to $596.2 \mathrm{\mu gm}^{-3}$ (observed during the night at $10 \mathrm{pm})$ [11]. The sum of NR-PM $(x=1$ or 2.5) and BC is represented here as the equivalent $\mathrm{PM}_{\mathrm{X}}$ concentration, which does not include refractory elements such

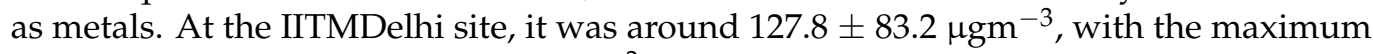
concentration reaching up to $391.3 \mu \mathrm{gm}^{-3}$ (observed during the morning at $9 \mathrm{am}$ ); whereas the mean hourly average $\mathrm{PM}_{1}$ (eq.) concentration during the sampling period at MRIIRS 
was $72.3 \pm 44.0 \mu \mathrm{gm}^{-3}$, with a maximum concentration of $250 \mu \mathrm{gm}^{-3}$ (observed during late night at $1 \mathrm{am}$ ). Chloride concentrations during the campaign were noted as very high at all three campaign sites (IITDelhi, IITMDelhi, and MRIIRS), with campaign mean concentrations of $20.4 \pm 30.3 \mu \mathrm{gm}^{-3}$ (max. $209.5 \mu \mathrm{gm}^{-3}$ ), $22.3 \pm 27.6 \mu \mathrm{gm}^{-3}$ (max. $126.4 \mu \mathrm{gm}^{-3}$ ), and $7.7 \pm 9.7 \mu \mathrm{gm}^{-3}\left(\max 68.2 \mu \mathrm{gm}^{-3}\right)$, respectively. Several other studies also reported high particulate chloride concentrations in Delhi [2,3]. Pant et al. reported $27.8 \mathrm{\mu gm}^{-3}$ of chloride in winter and identified coal combustion, biomass burning, and waste burning as the probable sources of particulate chloride [2]. Rai et al. found the mean of the total elemental $\mathrm{PM}_{10}$ mass was $\sim 271 \mu \mathrm{gm}^{-3}$ in the 2018 (20 January-11 March) campaign, and it was $\sim 300 \mu \mathrm{gm}^{-3}$ in the 2019 (15 January-9 February) campaign; the mean of total $\mathrm{PM}_{2.5}$ mass was $\sim 180 \mathrm{\mu gm}^{-3}$ during the 2019 campaign [12]. As reported by Wang et al., the sum of mixing ratios of all VOCs was $27.6 \mathrm{ppbv}$ at IITDelhi and $19.4 \mathrm{ppbv}$ at MRIIRS during the study period of 18 January to 10 March 2018 [13]. The means over the sampling period of organics, nitrate, sulfate, ammonium, chloride, $\mathrm{BC}$, and elemental $\mathrm{PM}_{2.5}$ reported by Lalchandani et al. and Rai et al. are listed in Table 2.

Table 2. The sampling period mean concentrations of organics, nitrate, sulfate, ammonium, chloride, $\mathrm{BC}$, elemental $\mathrm{PM}_{2.5}$, and VOCs (values are in $\mu \mathrm{gm}^{-3} \pm$ standard deviation, except for VOCs, which arein ppbv) as reported by Lalchandani et al. and Rai et al. [10,12].

\begin{tabular}{cccc}
\hline & IITDelhi & IITMDelhi & MRIIRS, Delhi \\
\hline Organics & $65.3 \pm 51.68$ & $55 \pm 37.4$ & $32.4 \pm 20.5$ \\
$\mathrm{NO}_{3}$ & $13.3 \pm 12.1$ & $11.1 \pm 8$ & $8 \pm 6.2$ \\
$\mathrm{SO}_{4}$ & $12 \pm 10.1$ & $12.5 \pm 5.3$ & $8.9 \pm 6.2$ \\
$\mathrm{NH}_{4}$ & $14.3 \pm 13.5$ & $13.6 \pm 11.4$ & $9 \pm 6.9$ \\
$\mathrm{Cl}$ & $20.4 \pm 30.3$ & $22.3 \pm 27.6$ & $7.7 \pm 10$ \\
$\mathrm{BC}$ & $24.5 \pm 20.6$ & $14.4 \pm 9.9$ & $3.3 \pm 2.4$ \\
$* \mathrm{PM}_{2.5 \text { elements }}$ & 32.6 & & 19.4 \\
VOCs & 27.6 & & \\
\hline
\end{tabular}

* Unlike the other types, $\mathrm{PM}_{2.5 \text { elements }}$ data obtained from Rai et al. is for the year 2019 in late winter instead of 2018, but for the same span of 17 January-11 March. No measurement for $\mathrm{PM}_{2.5 e l e m e n t s}$ was available for 2018 [12].

\subsection{Source Apportionment of Different Types of Aerosols Using a PMF Model}

In the studies by Lalchandani et al., Tobler et al., Rai et al. and Wang et al. source apportionment for the different types or sources of pollutants [10-13] was performed using the PMF model [24]. The multilinear engine (ME-2) algorithm (Paatero, 1999) was used to solve the PMF, and it was controlled via Source Finder (SoFi, Datalystica Ltd., Villigen, Switzerland) [25], interface version 6.6. The details of the model and its application are discussed in Lalchandani et al., Rai et al. and Wang et al. [10,12,13]. PMF is a receptor model. It is used to solve bilinear unmixing equations. A given quantity is factorized into a linear combination of a set of constant factor profiles and their corresponding time series. However, the limitation of PMF is that it can give mathematically accurate but not unique solutions, as it results in several linear combinations of the factor profile and time series, known as the rotations [26,27]. As a result, the factor profiles may appear in mixed status, and this will lead to an inaccurate estimation of the contribution of factors $[25,28,29]$. Applying ME-2, these rotations are efficiently explored by constraining one or more elements of the factor profile and/or time series in the PMF model and incorporating known information of source profile(s) and/or temporal variation as a priori information, referred to as the a-value approach. The a-value represents the degree of constraint on the known source profile and/or time series.

\subsubsection{Source Apportionment of Organic Aerosols (OAs)}

Tobler et al. and Lalchandani et al. have performed source apportionment of ambient organic aerosols (OAs) using a PMF model for New Delhi that revealed three main components of OAs, namely hydrocarbon-like OA (HOAs), which are related to vehicular emissions; solid fuel combustion OAs (SFC OAs); and oxygenated OAs (OOAs) [10,11]. The percentage contributions of these three components are shown in Figure 1. Lalchan- 
dani et al. used high-resolution mass spectra acquired with an HR-ToF-AMS to further apportion these three components into six factors consisting of one related to traffic (HOA), two related to solid fuel combustion (SFC-1 and SFC-2), three secondary factors (two freshly oxidized factors (SVOOA-1 and SVOOA-2) and one highly oxidized factor (LVOOA)) [10]. Primary OA factors such as HOAs and SFCs can be termed as locally generated, whereas oxidized OA factors such as LVOOAs and SVOOAs can be associated with regional and/or transported emissions, although a large fraction of OOAs also can be formed locally. Thus, it may become difficult to differentiate local and regional, based only on OA factorization. Trajectory analysis of the factors can be used as a supportive agent to inspect which fractions originated from long distances and which originated locally, but at finer transport scales; this again becomes associated with more uncertainty with reference to the processes involving the microphysical/chemical evolution of aerosol particles and downwind dispersion [30,31] (Anderson et al., 2003; Campbell et al., 2016).

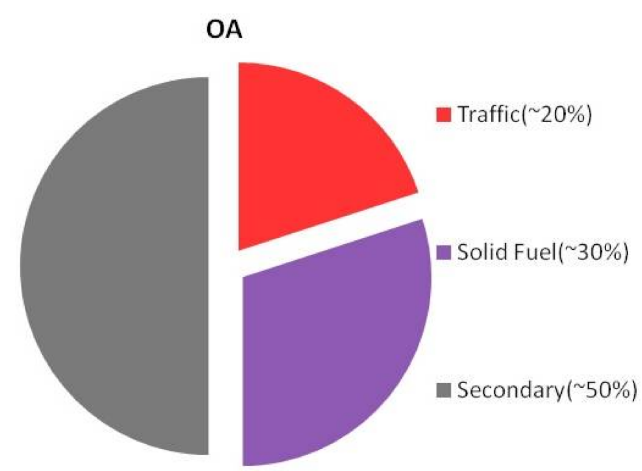

Figure 1. Fractional contributions of three major components of ambient organic aerosols (OAs) observed at IITDelhi (during 16 January-11 March 2018).

Tobler et al. and Lalchandani et al. both confirmed the presence of aliphatic hydrocarbon in HOAs and anhydrous sugars in SFC-OAs [10,11]. Lalchandani et al. more explicitly categorized the HOA mass by the presence of aliphatic hydrocarbon signals at $\mathrm{m} / \mathrm{z}$ $41\left(\mathrm{C}_{3} \mathrm{H}_{5}\right), 43\left(\mathrm{C}_{3} \mathrm{H}_{7}\right), 55\left(\mathrm{C}_{4} \mathrm{H}_{7}\right), 57\left(\mathrm{C}_{4} \mathrm{H}_{9}\right), 69\left(\mathrm{C}_{5} \mathrm{H}_{9}\right)$, and $71\left(\mathrm{C}_{5} \mathrm{H}_{11}\right)$ [10], all of which are characteristically linked with vehicular emissions [32]. The HOA factor showed a diurnal cycle at all sites, with a moderate peak in the morning hours between 9 to 10 am local time, and a sharp peak in the evening between 6 and $11 \mathrm{pm}$. Moreover, high overnight concentrations were observed, indicating high night-time vehicular emissions coupled with a shallow nocturnal boundary layer [8]. In this study, SFC- 1 and SFC-2 factors were categorized by the presence of the signals of anhydrous sugars at $m / z 60\left(\mathrm{C}_{2} \mathrm{H}_{4} \mathrm{O}_{2}\right)$ and $m / z 73\left(\mathrm{C}_{3} \mathrm{H}_{5} \mathrm{O}_{2}\right)$, and other oxidized fragments at $m / z 29(\mathrm{CHO}), m / z 43\left(\mathrm{C}_{2} \mathrm{H}_{3} \mathrm{O}\right)$, and $m / z 44\left(\mathrm{CO}_{2}\right)$. SFC-1 consists of ions (fragments) of chemical compounds that come from coal combustion, and also contains a small contribution of polycyclic aromatic hydrocarbons (anthracene and pyrene), which are usually emitted during incomplete combustion processes, whereas SFC-2 is found associated most likely with wood-burning emissions [10]. Both studies showed that the diurnal pattern of SFC had a small peak in the morning between 7 and 9 am, and a more prominent peak in the evening between 6 and $11 \mathrm{pm}$, which was reasonably consistent with residential cooking, heating, and other burning activities. Finally, for secondary factors, Tobler et al. found a major contribution of thermal decomposition of highly oxygenated organic acids, and some aliphatic organics [11]. Lalchandani et al. found that SVOOA-1 mass spectra could be characterized by signals at $m / z 53\left(\mathrm{C}_{4} \mathrm{H}_{5}\right), 67\left(\mathrm{C}_{5} \mathrm{H}_{7}\right), 81\left(\mathrm{C}_{6} \mathrm{H}_{9}\right), 95\left(\mathrm{C}_{7} \mathrm{H}_{11}\right)$, and $109\left(\mathrm{C}_{8} \mathrm{H}_{13}\right)$, along with aromatic fragments at $\mathrm{m} / z 63\left(\mathrm{C}_{5} \mathrm{H}_{3}\right), 77\left(\mathrm{C}_{6} \mathrm{H}_{5}\right), 91\left(\mathrm{C}_{7} \mathrm{H}_{7}\right)$, and $105\left(\mathrm{C}_{8} \mathrm{H}_{9}\right)$ [10]. The presence of aromatic compounds indicated that it originated from the oxidation of primary emissions rich in aromatic compounds emitted from vehicular exhausts, whereas SVOOA-2 consisted of nitrogen-containing fragments (CHN and CHNO) at $m / z 27,30,40,41$, and 42 , along with traces of biomass burning fragments at $m / z 60$ and 73 , indicating the oxidation of solid-fuel burning emissions. LVOOAs were categorized 
by very high signals at $m / z 44\left(\mathrm{CO}_{2}{ }^{+}\right)$, a relatively lower signal at $m / z 43\left(\mathrm{C}_{2} \mathrm{H}_{3} \mathrm{O}\right)$, and negligible signals at $m / z>44$, representing the presence of aged species in this factor [33].

Traffic-related emissions were the largest contributor to the total OA mass at the IITDelhi site ( $40 \%$ of the total OAs at midnight), whereas solid-fuel burning emissions were a major contributor ( $\sim 40 \%$ at midnight) to OAs at the IITMDelhi site, and the dominant contributor ( $\sim 60 \%$ at midnight) at the MRIIRS site. On the other hand, OOAs were found to be contributing a major (often dominant) part to the total OA mass (average relative contribution of $45-55 \%$ and up to $~ 70-80 \%$ during the afternoon hours), which was evidence of enhanced photo-oxidation of organics during the daytime. The concentrations varied significantly across the sites, but similarity of the PM chemical compositions and diurnal variations between the sites suggested similar types of sources and regional scale atmospheric processing of PM in Delhi and adjoining cities. Of course, the difference in mass concentrations across different sites indicated the influence of local emissions at the location of the particular site, rather than sources/emissions coherent across the whole region. The average (mean) of the components of OAs in $\mathrm{PM}_{2.5}$ data from IITDelhi and IITMDelhi (MIIRS was excluded, being a downwind site, but not exactly in Delhi) reported by Lalchandani et al. revealed that during the campaign span of mid-January to mid-March of 2018, the HOAs and SFC (i.e., both primary organic aerosols, POAs) contributed $20.5 \%$ and $29.5 \%$, respectively, and oxygenated OAs (i.e., mostly secondary organic aerosols, SOAs)contributed 50\% to the total OA mass in Delhi's atmosphere [10].

\subsubsection{Primary and Secondary Fraction of OAs from Offline Analysis}

In parity with the online estimation of primary and secondary fractions of OAs by Lalchandani et al. and Tobler et al. it is relevant to mention the results from the offline analysis by Bhowmik et al. to estimate POAs and SOAs $[10,11,14]$. SOAs have been estimated through an indirect method, based on the fact that EC can be used as a tracer for anthropogenic primary organic carbon (POC), as EC comes from primary emissions and is mostly inert in nature. This method is known as the EC-tracer method (Turpin et al., 1991). SOA and POA quantification by this method depends highly on the value of the primary $(\mathrm{OC} / \mathrm{EC})$ ratio. The primary OC/EC ratio is first used to estimate the secondary organic carbon (SOC). Then, the SOA mass concentration is estimated by multiplying SOC by a constant factor that takes into account the mass of other species present in secondary organic aerosols. In this study, a value of 2 was used based on the AMS-derived average ratio of organic matter to organic carbon $(\mathrm{OM} / \mathrm{OC}$ ) of $2.0 \pm 0.19$ (i.e., $\mathrm{OM}=2.0 \times \mathrm{OC}$ ) [10]. Thus, it was estimated using offline analysis that SOA and POA fractions over Delhi during mid-January to mid-March 2018 shared $50.3 \%$ and $49.7 \%$, respectively, of the OAs, which was clearly in good agreement with POA, and SOA fractions of OAs estimated by Lalchandani et al. using the online measurements [10].

\subsubsection{Source Apportionment of BC}

$\mathrm{BC}$ from biomass burning absorbs light in the ultraviolet (UV) and lower visible range more strongly than $\mathrm{BC}$ from fossil fuel combustion (e.g., traffic emissions), and therefore $\mathrm{BC}$ from these two sources have a different absorption Ångström exponent (AAE). This feature is used to apportion the proportional contributions of biomass burning and fossil fuel combustion emissions to total BC loading. Tobler et al. used an AAE value of 0.9 for traffic emissions and 1.5 for biomass burning emissions [11]. As observed by Lalchandani et al. at the IITDelhi site during the study period of mid-January to mid-March 2018, the fractional contributions from traffic emissions and biomass burning emissions were $\sim 67.5 \%$ and $\sim 32.5 \%$ of the total BC concentration, respectively, whereas at the IITMDelhi site, for the same study period, the contribution fractions of traffic emissions and biomass burning emissions were $\sim 55.7 \%$ and $\sim 44.3 \%$, respectively [10]. Singh et al. discussed that so far, BC was considered the only light-absorbing aerosol, and OC was considered to be a light-scattering aerosol [15]. Recent studies reported that a fraction of organic aerosols also absorbed light in the near-UV to the visible region, and thus such fraction 
of organic aerosols was categorized as brown carbon $(\mathrm{BrC})$ [34]. $\mathrm{BC}$ is emitted directly into the atmosphere [35], while BrC can either be emitted directly into the atmosphere or formed through secondary processes in the atmosphere. The contributions of $\mathrm{BC}$ and $\mathrm{BrC}$ absorption to the total absorption were estimated using the AAE method for both surface and columnar measurements [36].

\subsubsection{Source Apportionment of WS-BrC}

Rastogi et al. performed a PMF analysis of the total OAs (for the HR-LToF-AMS measured nonrefractory submicron aerosols) that provided six factors, namely hydrocarbon-like OAs (HOAs), two types of solid-fuel combustion OAs (SFCOA-1, SFCOA-2), two types of semivolatile oxygenated OAs (SVOOA-1, SVOOA-2), and low volatile oxygenated OAs (LVOOAs) [16]. A multiple regression analysis was performed between OA factors and BrC absorption observed at different wavelengths. The slope values (representing MAE of that factor) decreased exponentially from UV to visible regions for all the factors. The order of these MAEs were SFCOA-1 > SVOOA-1 > SVOOA-2 > SFCOA-2 > HOAs > LVOOAs indicating the absorption capacity of $\mathrm{BrC}$ from these respective source factors [16].

Additionally, a PMF analysis of WS-BrC spectra was also performed that resulted into a four-factor solution, representing specific sources of $\mathrm{BrC}$. Three factors demonstrated substantial diurnal variability with higher concentrations observed during morning rush hour. Factor 4 showed an unusual trend, peaking similar to SOAs, suggesting the presence of secondary BrC.

Differences in spectral characteristics of these four factors indicated that $\mathrm{BrC}$ came from different emission sources. Factor1 depicted the absorption in the UV region (at $300 \mathrm{~nm}$ ). This could be due to the presence of nitrate or other inorganic constituents in the spectrum. Factor2 displayed the absorption at both UV and visible regions, representing a typical $\mathrm{BrC}$ spectrum with higher absorption at UV and gradually reduced absorption values at higher wavelengths. Factor3 presented a very distinct $\mathrm{BrC}$ spectrum, with two humps peaking at $300 \mathrm{~nm}$ and $500 \mathrm{~nm}$. The second hump at $500 \mathrm{~nm}$ was likely associated with secondary BrC. Factor 4 was high during the day in spite of dilution, indicating a secondary nature [16].

\subsubsection{Source Apportionment of Elements in PM}

Rai et al. carried out the measurement of elements in $\mathrm{PM}_{10}$ and $\mathrm{PM}_{2.5}$ (denoted hereinafter as $\mathrm{PM}_{10 \text { elements }}$ and $\mathrm{PM}_{2.5 e l e m e n t s,}$ respectively) using an Xact $625 \mathrm{i}$ in Delhi during two consecutive winters (2018 and 2019), and performed their source apportionment using the PMF model [12]. This study reported details on elements in $\mathrm{PM}_{10}$ and $\mathrm{PM}_{2.5}$, their sources in Delhi such as dust and inorganic constituents (e.g., chloride), and potential health risks due to very high concentrations of carcinogenic elements $(\mathrm{Cr}, \mathrm{Ni}, \mathrm{As}, \mathrm{Pb})$ and other elements $(\mathrm{Cl}, \mathrm{Zn}, \mathrm{Cu}, \mathrm{Mn}, \mathrm{V}$, etc.). The ME-2 analysis yielded nine source profiles/factors in total, interpreted as dust, nonexhaust, SFC1, SFC2, and S-rich, with the remaining four related to industrial/combustion aerosol plume events (Cr-Ni-Mn, $\mathrm{Cl}-\mathrm{Br}-\mathrm{Se}, \mathrm{Cu}-\mathrm{Cd}-\mathrm{Pb}$, and $\mathrm{Pb}-\mathrm{Sn}-\mathrm{Se}$ ). Their fractional contributions are shown in Figure 2. Furthermore, the size-segregated SA analysis revealed that dust and nonexhaust sources dominantly contributed to $\mathrm{PM}_{10 \mathrm{el}}$, while the remaining factors (except $\mathrm{Cr}-\mathrm{Ni}-\mathrm{Mn}$ ) were in $\mathrm{PM}_{2.5 \mathrm{el}}$. It was reported that for Delhi, the features of the nonexhaust sources obtained were nearly similar to those of the road dust samples containing more than $60 \% \mathrm{Si}, \mathrm{Ca}$, $\mathrm{Ti}$, and $\mathrm{V}$ together with $\mathrm{Sr}$, and $\sim 40 \%$ of $\mathrm{Al}, \mathrm{Fe}$, and $\mathrm{Rb}$ together. The mass of this factor (fractional composition) was dominated by Si, Ca, Fe, Al, and $\mathrm{K}$. The nonexhaust factor contributed major fractions of total $\mathrm{Ba}(95 \%)$ and $\mathrm{Zr}(75 \%) ; 20-40 \%$ of $\mathrm{Al}, \mathrm{Si}, \mathrm{Ca}, \mathrm{Ti}, \mathrm{Mn}$, $\mathrm{Fe}, \mathrm{Rb}$, and $\mathrm{Sr}$; and $\sim 16 \% \mathrm{Cu}$. These metals are related to brake and tire wear. The time series of this factor showed a strong correlation with HOAs and traffic-related VOC factors. Next, the SFC1 factor contributed $>30 \%$ to the total K, Sb, and in; and $15-20 \%$ to $\mathrm{Mn}$, $\mathrm{As}, \mathrm{Rb}$, and $\mathrm{Sn}$. The mass of the factor was dominated by two elements, $\mathrm{K}(51 \%)$ and $\mathrm{S}(25 \%)$. The possible sources of SFC1 factor were crop residue burning, wood and coal 
combustion. Likewise, the SFC2 factor was composed mainly of $\mathrm{Zn}, \mathrm{S}, \mathrm{Cl}$, and $\mathrm{K}$ ( $26 \%$, $26 \%, 24 \%$, and $23 \%$ of the factor mass, respectively). SFC2 factors are supposed to be emitted from industrial/electronic waste burning, coal combustion and plastic burning. The S-rich factor was composed of S (92\% of the factor mass) as the dominant fraction among Se, $\mathrm{Cd}$, and in (from residue of thermal coal-based power plants). The $\mathrm{Cr}-\mathrm{Ni}-\mathrm{Mn}$ factor profile contained high relative contributions ofCr (98\%), Ni (64\%), and Mn (20\%), although $\mathrm{Fe}(25 \%), \mathrm{Al}(19 \%)$, and S (16\%) dominate the mass. Cr, Ni, and Mn were found to have association with traffic-related activities, industrial activities, waste incineration, solid waste dumping, and oil combustion. The $\mathrm{Cu}-\mathrm{Cd}-\mathrm{Pb}$ factor profile showed high relative contributions of $\mathrm{Cu}(78 \%), \mathrm{Cd}(53 \%)$, and $\mathrm{Pb}(19 \%)$, plus non-negligible contributions of $\mathrm{Sn}(19 \%), \mathrm{Sb}(18 \%)$, and $\mathrm{Br}(15 \%)$. However, $\mathrm{Cl}(33 \%)$ and $\mathrm{S}(30 \%)$ dominated the mass in this factor. The elements in this factor profile primarily were linked with various types of industrial emissions. The $\mathrm{Pb}-\mathrm{Sn}$-Se factor profile showed high relative contributions of $\mathrm{Pb}$ $(78 \%)$, Sn ( $54 \%)$, and Se $(19 \%)$, whereas the mass was dominated by S (37\%), Pb $(33 \%)$, and $\mathrm{Cl}(20 \%)$, and these were associated with emissions from open waste/plastic burning [12].

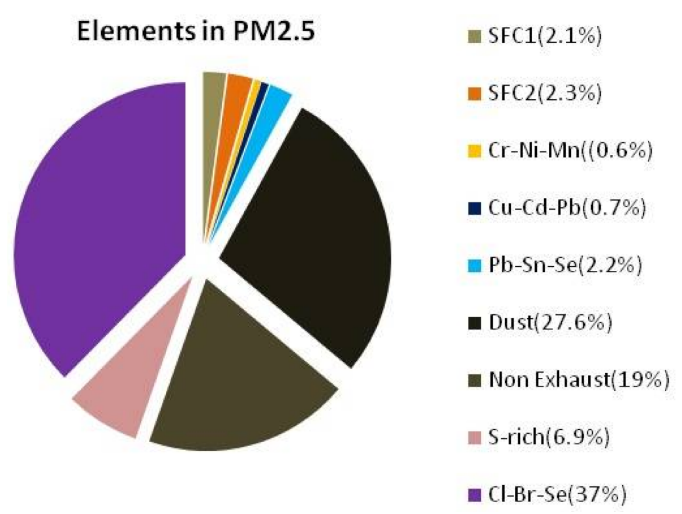

Figure 2. Fractional contributions of the factors of elements in $\mathrm{PM}_{2.5}$ samples collected in Delhi inwinter 2019.

The $\mathrm{Cl}-\mathrm{Br}-\mathrm{Se}$ factor showed high relative contributions for $\mathrm{Cl}(95 \%), \mathrm{Br}(62 \%)$, Se (32\%), and $\mathrm{Al}(20 \%)$, while the dominant mass was of $\mathrm{Cl}(89 \%)$. The high concentration of chlorine in Delhi could be due to HCL fumes reacting with ammonia gas present in the atmosphere. The HCL fumes are emitted from steel-processing industries present in Punjab and Haryana. The strong correlation of $\mathrm{Al}$ with $\mathrm{Cl}$ and $\mathrm{Br}$ as found in this study indicated that this profile was likely to come from metallurgical/chemical industries, coal combustion, and trash burning. Br has been reported to also come from wood combustion, waste incineration, and auto emissions. A comparative analysis dividing the campaign span of 2018 into two periods of cold (20 January-21 February) and warm (22 February-11 March), based on the ambient temperatures, was presented in Rai et al. (2020), and showed that the concentrations of the $\mathrm{Cl}-\mathrm{Br}-\mathrm{Se}$ and $\mathrm{Pb}-\mathrm{Sn}$-Se factors decreased with increases in ambient temperature and wind speed and a decrease in RH (relative humidity). In contrast, an enhancement in the dust factor during the warm period was noted as consistent with dryness in the ambient conditions [12].

Geographical origins of the resolved sources were also determined in the same study using the combination of an air mass back trajectory cluster footprint model and a concentration weighted trajectory (CWT) model. Dust, nonexhaust, and SFC1 were found to be of local origin (within Delhi). The sources of Cl-Br-Se were likely predominantly located northwest of the measurement site and influenced partly by the regional sources in Punjab and Haryana and partly by the local sources within Delhi. The S-rich and Cr-Ni-Mn factors were associated with air masses that originated in/passed over Uttar Pradesh (northeast to southeast). The $\mathrm{Cu}-\mathrm{Cd}-\mathrm{Pb}$ factor was associated with air masses from Nepal and Uttar Pradesh (east), and Pb-Sn-Se and SFC2 were found associated with air masses originating in Haryana, Punjab, and Pakistan (northwest) [12]. 


\subsubsection{Source Apportionment of VOCs}

A study by Wang et al. investigated the characteristics and sources of VOCs with highly time-resolved measurements using a proton-transfer-reaction time-of-flight mass spectrometer (PTR-ToF-MS) at two different sites simultaneously in New Delhi (at IITDelhi, an urban site; and at MRIIRS, a suburban site) from January-March 2018 [13]. Higher mixing ratios of VOCs were observed at the IITDelhi site, with higher night-time contributions from anthropogenic emissions compared to those at the MRIIRS site. The PMF resolved a six-factor solution at both sites that consisted of two factors each related to traffic, solid fuel combustion (SFC), and secondary sources, as shown in Figure 3.

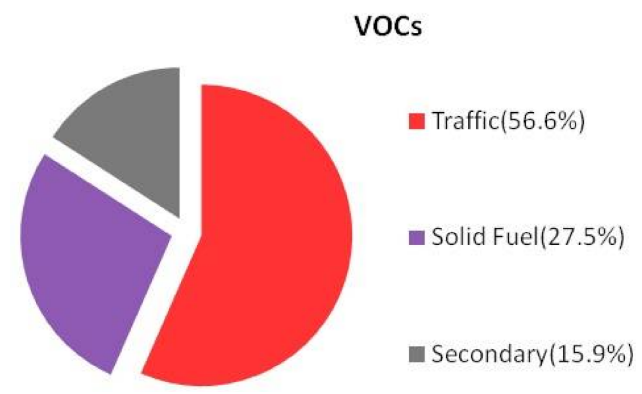

Figure 3. Fractional contribution of the factors of VOCs at IITDelhi (during 16 January-11 March 2018).

The first two factors (Traffic1 and Traffic2) were linked to vehicular emissions. The Traffic 1 factor was mainly contributed by light motor vehicles (LMVs), and Traffic 2 was related to emissions from heavy motor vehicles (HMVs). Both showed an increase during the night hours and a decrease during the daytime. The mass spectra of both Traffic1 and Traffic 2 showed abundance of aromatic $\mathrm{C}_{\mathrm{x}} \mathrm{H}_{\mathrm{y}}$ compounds, namely $\mathrm{C}_{6} \mathrm{H}_{6}$ $(m / z=79.054), \mathrm{C}_{7} \mathrm{H}_{8}(m / z=93.070), \mathrm{C}_{8} \mathrm{H}_{10}(m / z=107.086), \mathrm{C}_{9} \mathrm{H}_{12}(m / z=121.101)$, and $\mathrm{C}_{10} \mathrm{H}_{14}(m / z=135.117)$. These ions were likely due to benzene, toluene, and $\mathrm{C}_{8}$ to $\mathrm{C}_{10}$ aromatics, which are well-known markers for vehicular emissions (Yao et al., 2015; Cao et al., 2016). In addition, Traffic2 also included relatively high contributions from nonaromatic hydrocarbons and some oxygenated organic compounds [13].

Two solid fuel combustion factors were named as SFC1 and SFC2. SFC1 was characterized by high loadings of aromatics, as well as oxygenated ions, such as $\mathrm{C}_{6} \mathrm{H}_{6}\left(\mathrm{C}_{\mathrm{n}} \mathrm{H}_{2 n}\right) \mathrm{O}_{1}$, $\mathrm{C}_{6} \mathrm{H}_{6}\left(\mathrm{C}_{\mathrm{n}} \mathrm{H}_{2 \mathrm{n}}\right) \mathrm{O}_{2}, \mathrm{C}_{4} \mathrm{H}_{4}\left(\mathrm{C}_{\mathrm{n}} \mathrm{H}_{2 n}\right) \mathrm{O}_{1}, \mathrm{C}_{4} \mathrm{H}_{4}\left(\mathrm{C}_{\mathrm{n}} \mathrm{H}_{2 n}\right) \mathrm{O}_{2}$, and $\mathrm{C}_{5} \mathrm{H}_{4} \mathrm{O}_{1-2}$, which were likely due to phenolic compounds and furans (Stockwell et al., 2015; Bruns et al., 2017). SFC1 was found prominently related to primary emissions from solid fuel combustion, which might include many types of biomass burning, combustion of coal, and even trash combustion. Benzene was the dominant species in the SFC2 factor, followed by toluene, and only small amounts of reactive phenols and furans were present. Moreover, SFC2 consisted of a significant fraction of nocturnal nitrophenol mixing ratios, indicating the night-time aging of SFC emissions. In addition, it included a high mass fraction of $\mathrm{N}$-containing compounds, such as $\mathrm{C}_{3} \mathrm{H}_{3} \mathrm{~N}, \mathrm{C}_{4} \mathrm{H}_{5} \mathrm{~N}$, and $\mathrm{C}_{7} \mathrm{H}_{5} \mathrm{~N}$ [13].

VOCs are reactive and significantly contribute to secondary organic aerosol (SOA) formation. Two secondary VOCs factors (SecVOC1 and SecVOC1) were distinguished from the other factors by the prevailing presence of oxygenated compounds. SecVOC1 consisted of large fractions of $\mathrm{C}_{2} \mathrm{H}_{4} \mathrm{O}_{3}$ and $\mathrm{C}_{4} \mathrm{H}_{2} \mathrm{O}_{3}$, and the $m / z$ spectrum was dominated by $\mathrm{C}_{4} \mathrm{H}_{8} \mathrm{O}, \mathrm{C}_{3} \mathrm{H}_{4} \mathrm{O}_{2}, \mathrm{C}_{3} \mathrm{H}_{6} \mathrm{O}_{2}$, and $\mathrm{C}_{3} \mathrm{H}_{6} \mathrm{O}_{3}$ fragments, although their relative contributions to these ions were comparably lower than to $\mathrm{C}_{2} \mathrm{H}_{4} \mathrm{O}_{3}$ and $\mathrm{C}_{4} \mathrm{H}_{2} \mathrm{O}_{3}$. The diurnal pattern of SecVOC1 followed that of the solar radiation, with a sharp increase starting from around 7 am local time (LT), then declining continuously after 1pm LT. Many of these ions can be formed rapidly during the daytime, and they may have a short lifetime due to the possibilities of gas-to-particle partitioning process (Wang et al., 2020). SecVOC2 had noteworthy contributions from $\mathrm{C}_{3} \mathrm{H}_{4} \mathrm{O}_{2}$ and $\mathrm{C}_{3} \mathrm{H}_{6} \mathrm{O}_{2}$ as well, but the relative contributions to $\mathrm{C}_{3} \mathrm{H}_{4} \mathrm{O}_{2}, \mathrm{C}_{4} \mathrm{H}_{6} \mathrm{O}_{2-3}, \mathrm{C}_{6} \mathrm{H}_{6} \mathrm{O}_{2}, \mathrm{C}_{8} \mathrm{H}_{8} \mathrm{O}_{3}$, and $\mathrm{C}_{6} \mathrm{H}_{5} \mathrm{NO}_{3}$ weremuch higher than for the $\mathrm{SecVOC1}$, along with many oxygenated compounds with higher molecular weight. Thus, 
it was inferred by Wang et al. (2020) that SecVOC1 was a mix of first-generation products and later-generation oxidation products, while SecVOC2 was likely to be linked with second-generation products and night-time chemistry [13].

Anthropogenic emissions were shown to be major VOC sources at both sites. More precisely, at the urban site (IITDelhi), traffic-related emissions were found to be the dominant source, contributing $56.6 \%$; while SFC contributed $27.5 \%$; and secondary formation, which is the most important source of VOCs during daytime, had contributed $15.9 \%$ to the total analyzed VOC mixing ratio. At the suburban site (MRIIRS), traffic-related emissions were $36.0 \%$, followed by secondary formation and SFC contributions of $33.6 \%$ and $30.4 \%$, respectively, to the total VOC mixing ratio. Higher mixing ratios of oxygenated VOCs were found at the suburban site, feasibly due to the suppression of oxidant levels in the urban atmosphere and a comparatively longer aging time at the suburban site. The diurnal patterns and profiles of the factors indicated that the anthropogenic sources were similar at both sites, even though the VOC mixing ratios at MRIIRS were much lower than at IITDelhi. In contrast, both the diurnal variations and spectra of secondary factors were significantly different at the two sites, exhibiting higher mixing ratios and contributions at the suburban site, especially during the daytime. At IITDelhi, the two secondary VOC factors were found to have different aging processes such as fast photochemical formation and later-generation production under strong primary emissions, whereas at the MRIIRS suburban site, local oxidation and regional aging, such asformation of peroxyacetyl nitrate (PAN), were dominant in VOC oxidation with $\mathrm{NO}_{x}$ [37] (de Gouw and Warneke, 2007). In addition, evaluation of biogenic markers (methyl vinyl ketone and methacrolein) indicated a very small contribution from biogenic emissions and their oxidation products. The findings prominently indicated the major role of anthropogenic sources in the pollution levels and variations in characteristics of ambient VOCs in Delhi [13].

\subsection{Case Study: Analysis of Changes in All Pollutants during a Two-Week Span}

The time series of $\mathrm{PM}_{2.5}$, elements, and VOCs over the study period of 17 January11 March 2018 presented in Lalchandani et al., Rai et al. and Wang et al. [10,12,13] respectively showed a notable span of two weeks from 13-26 February 2018 (as shown if Figure 4 and elaborated in Figure 5) when VOCs, $\mathrm{OA}, \mathrm{SO}_{4}, \mathrm{NO}_{3}, \mathrm{BC}$, and all elements (excluding $\mathrm{Cl}$ containing factor) had shown a gradual but steady increase (shown in Figures 4 and 5) at their corresponding sites (Figures 4 and 5 show only IITDelhi site plots, as it is a common site regarding all pollutant data availability), while $\mathrm{NH}_{4}$ and chloride (mostly in the form of $\mathrm{NH}_{4} \mathrm{Cl}$ ) had decreased. At the end of the two weeks, concentrations of every pollutant, exceptNH${ }_{4}$ and chloride, showed a sudden fall, whereas $\mathrm{NH}_{4}$ and chloride began increasing at this point.

The increase or decrease in species mentioned above may be interestingly correlated with any changes in the meteorological conditions or changes in sources. It can be mentioned here that $\mathrm{BC}$ from traffic showed much more prominent increase compared to $\mathrm{BC}$ from wood burning during this two-week period, as found in the figures by Lalchandani et al. and in the figures by Wang et al., it was found that the increase in the traffic (1 and 2) factors was more rapid and stronger compared to SFC factors in this two-week period $[10,13]$. The concentrations of particulate chloride and $\mathrm{NH}_{4}$ may have decreased gradually due to higher ambient temperatures and a lower relative humidity, conditions that are not favorable for the formation of/partition into particulate phase $\mathrm{NH}_{4} \mathrm{Cl}$, over the two-week period [2,12] Wang et al. reported a sharp increase in ambient temperatures after 21 February 2018 and a sudden drop at the end of the two-week period, likely associated with a rainfall event, but not mentioned in their studies [13]. However, the sudden fall in concentrations of other pollutants after 26 February 2018 indicated a sudden change, such as the washout effect that normally occurs due to rains. 

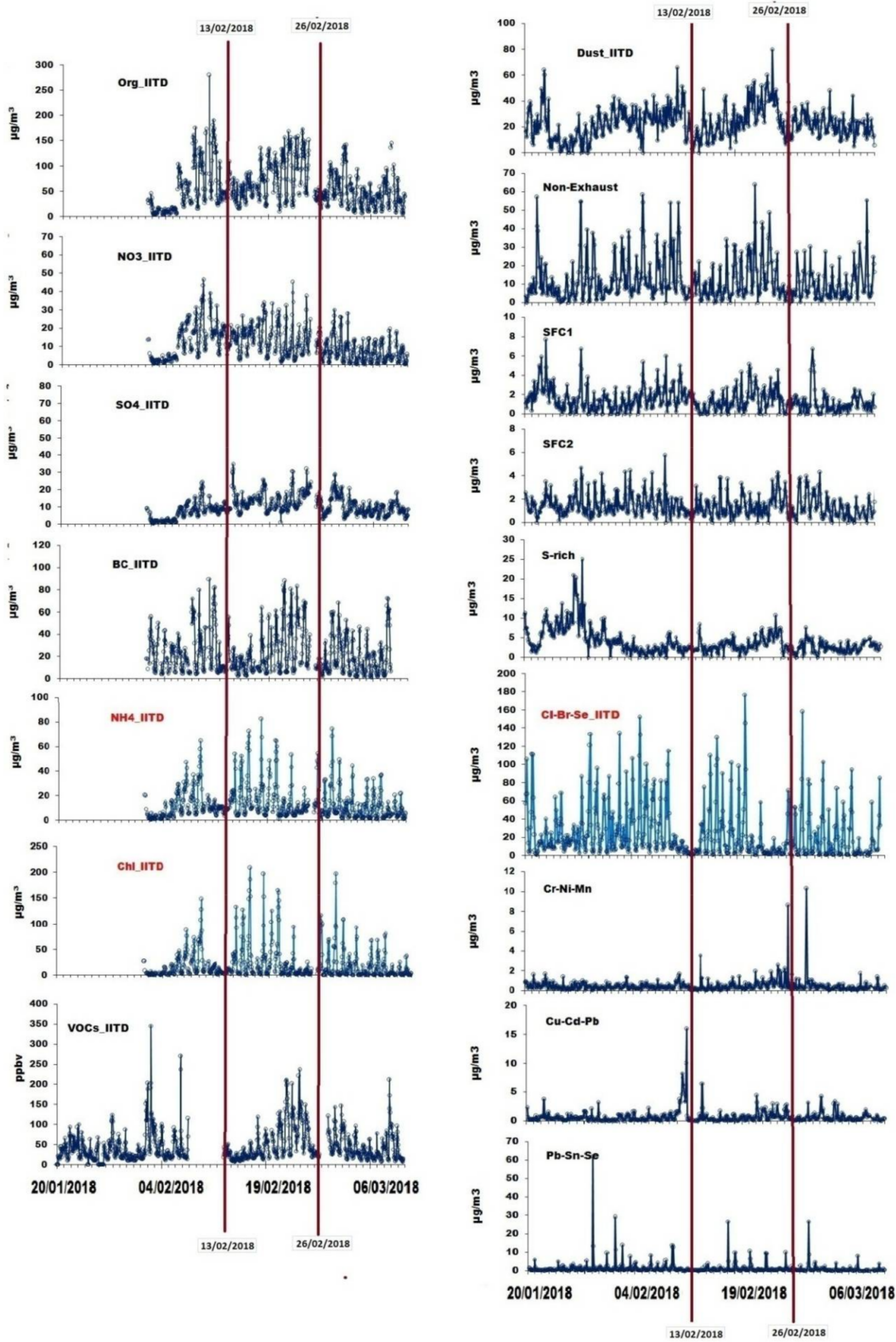

Figure 4. Time series of particulate $\mathrm{OA}, \mathrm{NO} 3, \mathrm{BC}, \mathrm{SO} 4, \mathrm{NH} 4, \mathrm{Chl}$, gaseous VOCs, and nine factors of elements at the IIT Delhi site for the span of the study period from Lalchandani et al., Wang et al. and Rai et al. [10,12,13]. Vertical red lines indicate the phase of gradual changes in all pollutants during the two-week period of 13-26 February 2018. 

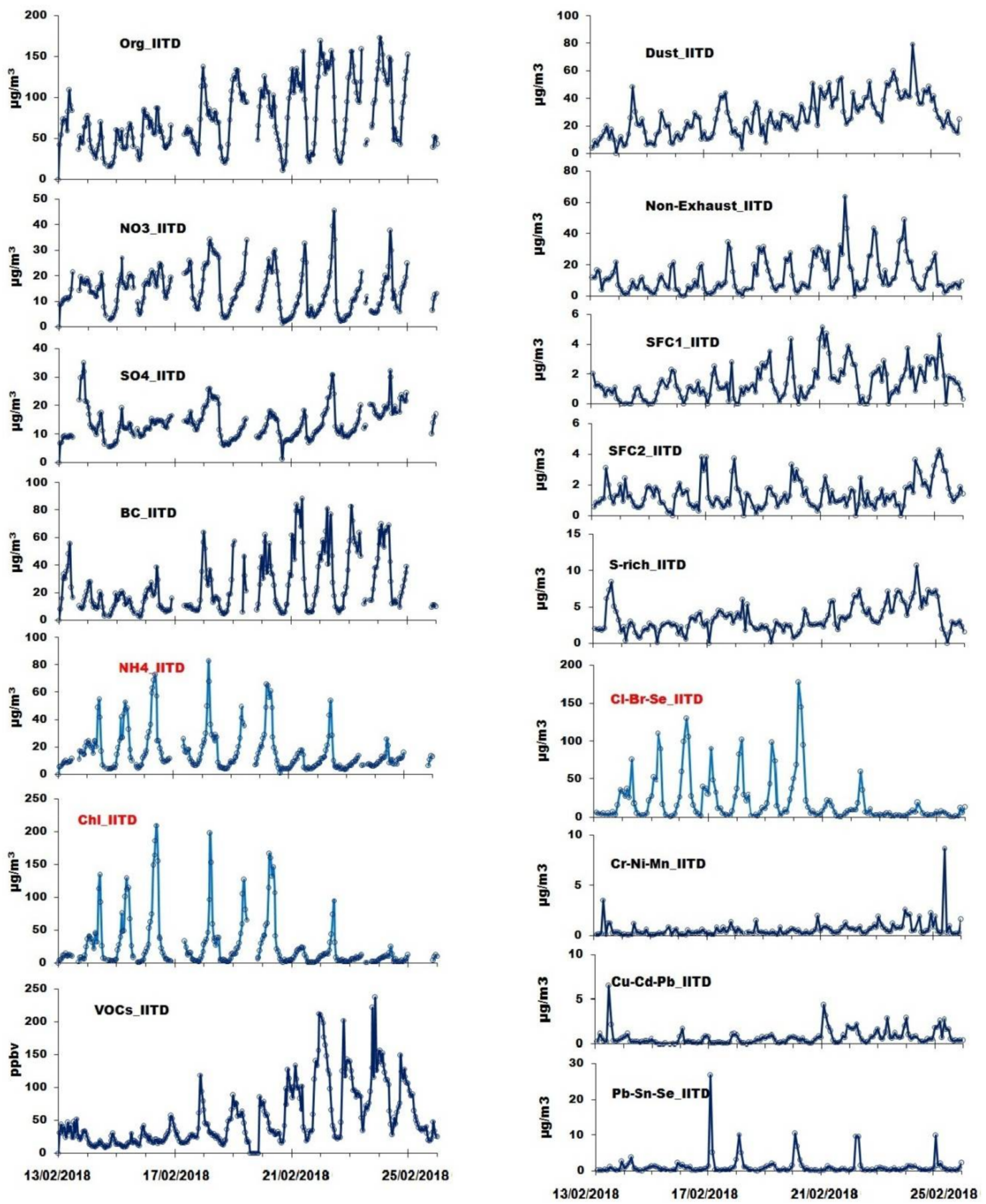

Figure 5. Time series of particulate $\mathrm{OA}, \mathrm{NO} 3, \mathrm{BC}, \mathrm{SO} 4, \mathrm{NH} 4, \mathrm{Chl}$, gaseous VOCs, and nine factors of elements (dust, nonexhaust, SFC1, SFC2, S-rich, Cr-Ni-Mn, Cl-Br-Se, Cu-Cd-Pb, and Pb-Sn-Se) during 13-26 February 2018 at the IITDelhi site.

\subsection{Categorization of the Sources of $P M_{2.5}$ and VOCs}

The abovementioned past studies created a scope of categorization of the sources of $\mathrm{PM}_{2.5}$ and VOCs in Delhi. It can be noted from all the SA analyses performed that all types of fine aerosols and VOCs were emitted from five major sources that are simultaneously contributing to the total loading of the $\mathrm{OA}, \mathrm{BC}$, elements in $\mathrm{PM}_{2.5}$, and VOCs in the atmosphere over Delhi-NRC. These five sources (as shown in Figure 6) are: (i) traffic-related emissions (which contribute to OA, BC, elements, and VOCs); (ii) solid fuel combustion (which contributes to $\mathrm{OA}, \mathrm{BC}$, elements, and VOC); (iii) secondary sources (which con- 
tribute major fractions to OA and VOCs); (iv) industrial activities (which contribute to elements); and (v) waste-burning events (which contribute to elements).
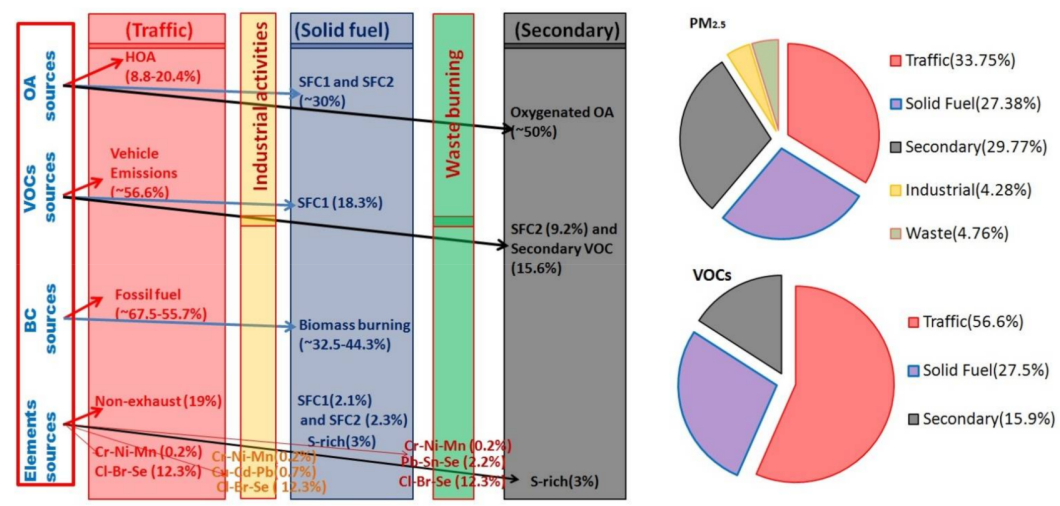

Figure 6. Fractional contributions of the major five sources of different types of $\mathrm{PM}_{2.5}$ and VOCs in Delhi during late winter.

It can be inferred from the fractional contributions of these five sources of different pollutants in Delhi that together, emissions from traffic-related and solid fuel combustion, the two primary sources, are vital sources of the total loading of pollutants in Delhi's environment, and therefore control of these two primary sources may decrease the formation of secondary pollutants, as well as total pollutant concentration to some extent.

\subsection{PM 2.5 Pollution Scenario as Reported from Some Important Urban Sites in Asia}

This section highlights $\mathrm{PM}_{2.5}$ source-attribution studies from other important sites in Asia conducted in the recent past to reach a comparative understanding of $\mathrm{PM}_{2.5}$ levels and sources in Delhi. In Beijing, the mean $\mathrm{PM}_{2.5}$ concentration as reported by Zang et al. during April 2009-January 2010 was $135 \pm 63 \mu \mathrm{gm}^{-3}$, and they attributed ambient $\mathrm{PM}_{2.5}$ to main seven potential sources: secondary inorganic aerosols, industrial pollution, coal combustion, mineral dust, biomass burning, traffic, and waste incineration [38]. Yu et al. (2013) reported an annual average $\mathrm{PM}_{2.5}$ concentration of $55.4 \pm 40.2 \mu \mathrm{g} / \mathrm{m}^{3}$ in 2010 (daily mean in the range 9.8-219 $\mathrm{\mu gm}^{-3}$ ) and identified seven sources and their fractional contributions in Beijing: secondary sulfur (26.5\%), vehicle exhaust (17.1\%), fossil fuel combustion $(16.0 \%)$, road dust $(12.7 \%)$, biomass burning $(11.2 \%)$, soil dust $(10.4 \%)$, and metal processing (6.0\%) [39]. In Haikou, the capital city of Hainan Province in southern China, the average $\mathrm{PM}_{2.5}$ concentration was $23.3 \mu \mathrm{gm}^{-3}$ for the period of 2013-2015 [40] with major contributions from secondary sulfate $(9.9-21.4 \%)$, resuspended dust $(10.1-19.0 \%)$, and vehicle exhaust (10.5-20.2\%). The annual average $\mathrm{PM}_{2.5}$ concentration in Seoul, South Korea, as reported by Heo et al. (2009) was $43.5 \mu \mathrm{gm}^{-3}$ [41]. Nine $\mathrm{PM}_{2.5}$ source categories were identified: secondary nitrate $(20.9 \%)$, secondary sulfate $(20.5 \%)$, gasoline vehicles $(17.2 \%)$, biomass burning $(12.1 \%)$, diesel emissions $(8.1 \%)$, soil $(7.4 \%)$, industry $(6.7 \%)$, road salt and two-stroke vehicles (5.1\%), and aged sea salt (2.2\%). Similarly, a study over the port city of Busan (South Korea) [42] found that the annual average $\mathrm{PM}_{2.5}$ concentration was $26.1 \pm 15.3 \mathrm{\mu gm}^{-3}$, and it was shown that the secondary formation of aerosols was the dominant (45-60\%) contributor to $\mathrm{PM}_{2.5}$ loading. The PMF and PCA/APCS analyses suggested that ship emissions were a non-negligible contributor to $\mathrm{PM}_{2.5}$ (up to about $10 \%$ ) in the study area. Here, this annual average $\mathrm{PM}_{2.5}$ in Busan was comparable with that in one of the major hub port cities of the world, Hong Kong $\left(30.5 \mu \mathrm{g} / \mathrm{m}^{3}\right)$ [43]. For a roadside site in Hong Kong, Cheng et al. (2014) reported the annual average mass concentration for $\mathrm{PM}_{2.5}$ was $55.5 \pm 25.5$, and seven sources were resolved using a PMF model: vehicle emissions $(\sim 29 \%)$, secondary inorganic aerosols ( $27 \%)$, waste incinerator/biomass burning $(\sim 23 \%)$, residual oil combustion $(\sim 10 \%)$, marine aerosols $(\sim 6 \%)$, industrial exhaust $(\sim 4 \%)$, and resuspended road dust $(\sim 1 \%)$. It is remarkable to note here that secondary sources of $\mathrm{PM}_{2.5}$ wereubiquitous and abundant (sometimes contributing up to $40 \%$ ) over most of East Asia [44]. 
A study in Bangkok, Thailand, by Wimolwattanapun et al. (2011) [45] reported the annual average mass concentrations of $\mathrm{PM}_{2.5}$ was $23.2 \mu \mathrm{gm}^{-3}$, and source apportionment using PMF identified these factors: construction/soil $(13.68 \pm 9.66 \%)$, soil (coarse) $(12.16 \pm 9.71 \%)$, road dust $(9.08 \pm 7.97 \%)$, traffic $(7.65 \pm 4.42 \%)$, aged sea salt $(5.35 \pm 4.70 \%)$,biomass $(4.51 \pm 4.17 \%)$, secondary sulfate $(2.39 \pm 2.49 \%)$, soil (fine) $(2.21 \pm 2.00 \%)$, sea salt $(1.27 \pm 1.50 \%)$, and $\mathrm{Zn}$ rich $(0.88 \pm 0.79 \%)$. Similarly, in the Kathmandu Valley, Nepal, located in the foothills on the southern flank of the central Himalayas in South Asia, Islam et al. (2020) [46] reported, based on daytime and night-time filter sampling, an average (mean) $\mathrm{PM}_{2.5}$ concentration of $68.2 \pm 34.7 \mu \mathrm{g} \mathrm{m}^{-3}$ during 11-24 April 2015, mainly composed of (nonwater mass of $\mathrm{PM}_{2.5}$ ) organic matter $(48 \%)$, sulfate $(16 \%)$, elemental carbon (13\%), ammonium $(9 \%)$, nitrate $(4 \%)$, chloride $(2 \%)$, calcium $(1 \%)$, potassium $(1 \%)$, and magnesium $(0.05 \%)$. Furthermore, the CMB analysis of OC, combined with source tracers, in Kathmandu Valley revealed five primary sources (garbage burning $18.1 \pm 4.5 \%$, gasoline and diesel engines $18.0 \pm 9.2 \%$, open biomass burning $17.2 \pm 9.5 \%$, coal combustion $5.0 \pm 2.3 \%$, and vegetative detritus $1.6 \pm 0.9 \%$ ), four secondary sources (naphthalene SOC $9.8 \pm 4.0 \%$, $\beta$-caryophyllene SOC $4.6 \pm 1.5 \%$, $\alpha$-pinene SOC $0.13 \pm 0.07 \%)$, and one unresolved or other source of OC $(25.4 \pm 16.6 \%)$ (Islam et al., 2020). Table 3 presents a comparison between the above-mentioned sites.

Table 3. The fractional contributions (in\%) of three major sources to $\mathrm{PM}_{2.5}$ at different urban sites in Asia (the details are in the main text).

\begin{tabular}{cccc}
\hline Site (Sampling Year) & Traffic Emissions & $\begin{array}{c}\text { Biomass } \\
\text { Burning/SFC }\end{array}$ & Secondary Aerosols \\
\hline Delhi (2018) & 33.75 & 27.38 & 29.77 \\
\hline Beijing (2010) & 17.1 & 11.2 & 26.5 \\
\hline Haikou (2013-2015) & $10.5-20.2$ & - & $9.9-21.4$ \\
\hline Seoul (2009) & 27.9 & $13.6 \pm 11.4$ & 41.4 \\
\hline Hong Kong (2014) & 29 & 23 & 27 \\
\hline Bangkok (2011) & $7.65 \pm 4.42$ & $4.51 \pm 4.17$ & $2.39 \pm 2.49$ \\
\hline
\end{tabular}

It was notable in the above-mentioned studies that Delhi's PM $_{2.5}$ concentration was higher than at all these important urban sites. The percentage contribution of biomass burning to $\mathrm{PM}_{2.5}$ in capitals such as Beijing, Seoul, or Bangkok, as reported, were less than that in Delhi; whereas contributions of traffic emissions and secondary sources to $\mathrm{PM}_{2.5}$ in Delhi were comparable to the other sites mentioned here.

\subsection{Potential Health Impacts of Offline Particulate Matters Using Oxidative Potential}

Fine particulate matter, due to its tiny size and the presence of toxic elements, can cause severe health impacts such asasthma, cardiovascular diseases, and pulmonary and respiratory illnesses. It has been found that ultrafine air pollutants can significantly affect the central nervous system (CNS) and can cause neurological diseases either by directly entering into the CNS or through developing systemic inflammations $[47,48]$ (Bandyopadhyay, 2016; Genc et al., 2012). Air pollution (mainly particulate matter) accounts for $>12.5 \%$ of the total deaths in a year in India [4] (Balakrishnan et al., 2019). Delhi experiences the worst air quality, especially in winter due to low wind speeds and a shallow boundary layer. The hourly averaged $\mathrm{PM}_{2.5}$ mass concentrations have been reported to exceed even $500 \mathrm{\mu gm}^{-3}$, which is $>8$ times higher than the National Ambient Air Quality Standards $\left(60 \mu \mathrm{gm}^{-3}\right.$ for $24 \mathrm{~h}$ average concentration), and exposure to this intensity of $\mathrm{PM}_{2.5}$ is a major public health risk and certainly a major concern for any nation.

In their study, Puthussery et al.,worked on measuring the potential of the adverse health impacts of $\mathrm{PM}_{2.5}$ over Delhi (for $\sim 1$ week) utilizing the oxidative potential (OP), which is a metric commonly used to determine aerosol exposure and its adverse health effects [17]. This study was the first to articulate real-time measurements of ambient $\mathrm{PM}_{2.5}$ OP based on a dithiothreitol (DTT) assay in Delhi, during the late winter season of 2019 
(February 2019). The OP of PM is known as the ability of particles to produce reactive oxygen species (ROS) or consume antioxidants. The DTT assay is a commonly used, lowcost, and easy-to-use chemical assay to measure the OP of ambient PM. DTT acts as electron donor in the presence of ambient PM and converts oxygen to its superoxide radical. The rate of oxidation of DTT during this reaction (referred to as the DTT activity) is assumed to be proportional to the amount of redox-active types present in ambient PM. Puthussery et al. performed the first-ever measurements of the real-time $\mathrm{PM}_{2.5} \mathrm{OP}$ in Delhi using an indigenous online instrument based on a DTT assay [17]. The real-time OP instrument had the benefit of capturing $1 \mathrm{~h}$ time-resolved data and showed fewer chances to lose short-lived radicals and unstable redox-active types. In this study, it was shown that DTT activity was best correlated with the oxygenated organic aerosols (OOAs). On the other hand, correlation among $\mathrm{SO}_{4}{ }^{2-}$, OOAs and OP led the authors to the hypothesis that both intrinsically redox-active SOAs formed during the afternoon, and the elevated aerosol mass concentrations at night, due to a stable nocturnal boundary layer mostly influencing the OP. In addition to the oxygenated organics, OP showed correlation with $\mathrm{K}$ which is commonly used as a tracer for biomass burning (BB) emissions.

\section{Summary and Conclusions}

The traditional approach of source attribution of particulate matter (PM) combining $\mathrm{PM}$ chemical composition (through filter sampling and offline analysis) and application of source-apportionment tools such as chemical mass balance (CMB) or positive matrix factorization (PMF), or more sophisticated chemical-transport modeling tools (e.g., WRFChem, CMAQ, CAMx), helps to estimate proportional contributions of various potential sources to observed PM concentrations. The recent advances in online measurement of different components of PM or mixing ratios of various gaseous species (e.g., VOVs) provides unprecedented opportunities to gain insights into the detailed composition of PM or characteristics of gaseous species and their potential sources, and when combined with PMF or CBM techniques, can help identify major sources and quantify their proportional contributions. This study provided a comprehensive assessment of the findings of recent studies using offline and online methods in Delhi, the capital city of India. Recent studies that used online techniques [10-12] reported organics, chloride, ammonium, sulfate, nitrate, black carbon, and elements as the major components of $\mathrm{PM}_{2.5}$ in the Delhi-National Capital Region (NCR) during the campaign in the late winter period of 2018. The highest PM concentrations during the campaign were observed at the Indian Institute of Technology Delhi (IITDelhi) site in Delhi city area, with a campaign hourly average $\mathrm{PM}_{2.5}$ (eq.) $\left(\mathrm{NR}^{\mathrm{P}} \mathrm{PM}_{2.5}+\mathrm{BC}\right.$ ) concentration of $153.8 \pm 109.4 \mathrm{\mu gm}^{-3}$, and a maximum concentration reaching up to $596.2 \mathrm{\mu gm}^{-3}$. Source apportionment of organic aerosols (OAs) using online measurements revealed a six-factor solution consisting of one traffic-related factor (HOAs), two solid-fuel combustion(SFC) related factors (SFC-1 and SFC-2), and three secondary factors (two freshly oxidized factors (SVOOA-1 and SVOOA-2) and one highly oxidized factor (LVOOA)). The offline technique estimated the contribution of SOAs (50.3\%) and POAs (49.7\%) to $\mathrm{PM}_{2.5}$ over Delhi during January to March 2018, which agreed well with the estimation of primary and secondary OA fractions estimated using the online measurements. Furthermore, source apportionment of the elements in $\mathrm{PM}_{10}$ and $\mathrm{PM}_{2.5}$ (i.e., $\mathrm{PM}_{10 \text { element }}$ and $\mathrm{PM}_{2.5 e l e m e n t}$ ) yielded nine source profiles that were interpreted as dust, nonexhaust, SFC-1, SFC-2, sulfur-rich, and four industrial/combustion aerosols related to plume events (Cr-Ni-Mn, $\mathrm{Cl}-\mathrm{Br}-\mathrm{Se}, \mathrm{Cu}-\mathrm{Cd}-\mathrm{Pb}$, and $\mathrm{Pb}-\mathrm{Sn}-\mathrm{Se}$ ).

$\mathrm{PMF}$ analysis of water-soluble $\mathrm{BrC}$ spectra resulted in a four-factor solution, representing specific sources of $\mathrm{BrC}$. Three factors demonstrated substantial diurnal variability with higher concentrations observed during the morning rush hour. Factor 4 showed an extraordinary trend, peaking similar to SOA, suggesting the presence of secondary BrC.

Sources of volatile organic compounds (VOCs) at two different sites in New Delhi (an urban site at IITDelhi and a suburban site at MRIIRS), India, from January to March 2018, 
as reported using positive matrix factorization (PMF), were two traffic factors, two solid fuel combustion (SFC) factors, and two secondary factors.

Overall, from all the results of the SA analyses performed in the mentioned individual studies, it was found that there were five major sources of fine PM and VOCs that pollute the atmosphere over Delhi-NRC: (i) traffic-related emissions (which contribute to OA, BC, elements, and VOCs); (ii) solid fuel combustion (which contributes to OA, BC, elements, and VOC); (iii) secondary aerosol formation (which contributes mainly to OA and VOCs); (iv) industrial activities (which contribute mainly to elements); and (v) waste-burning events (which contribute mainly to elements).

Furthermore, a report from a first-ever real-time measurement of ambient $\mathrm{PM}_{2.5}$ oxidative potential (OP), a metric commonly used to determine aerosol exposure and its adverse health effects based on a dithiothreitol (DTT) assay, in Delhi during a late winter season of 2019 (February 2019), revealed DTT activity was best correlated with the oxygenated organic aerosols (OOAs).

Air pollution in Delhi (or in India as a whole) is a dynamic process with very strong seasonal variations due to seasonal changes in meteorological conditions, such as monsoon circulation and rains, and major sources such as agro-residue burning and brick production. It is expected that the nature of sources and characteristics of air pollutants will continue to change over the years with rapidly growing socio-economic activities and implementation of various clean air solutions and other policy measures. Therefore, it is of utmost importance to continue comprehensive source apportionment of particulate matter and gaseous air pollutants (e.g., VOCs) together, at least once every season, which is currently not available, so that the policy responses can be tailored appropriately and made adaptive to the evolving dynamics of air pollution in Delhi.

This study, which consolidated the recent findings on sources of PM and VOCs in Delhi based on state-of-the art sophisticated measurement and analysis techniques, will be useful in making a comprehensive assessment of the sources (and their contributions) of fine particulate pollutants and gaseous VOCs together in the Delhi National Capital Region; such assessment is currently contained in fragments in different studies. This will be vital to further enhancing our understanding of the composition, characteristics, and sources of air pollutants over Delhi in order to take one step ahead toward appropriate future research studies and mitigation measures for the local conditions informed by solid scientific evidence.

Author Contributions: Conceptualization, S.T. and S.N.T.; data curation, V.L., H.S.B., A.K.S., N.T., J.D. and N.R.; investigation, S.N.T.; resources, V.L., M.R., H.S.B., A.K.S., V.M., R.S., V.J., J.D., N.R., and L.S.; supervision, S.N.T.; visualization, S.T. and V.L.; writing-original draft, S.T., S.N.T., V.L., and M.R.; writing—review and editing, S.T., S.N.T., V.L., M.R., H.S.B., A.K.S., V.M., R.S., V.J., N.T., N.R. and L.S. All authors have read and agreed to the published version of the manuscript.

Funding: This work was financially supported by the Central Pollution Control Board (CPCB), Government of India, and conducted under grant no. AQM/Source apportionment_EPC Project/2017.

Institutional Review Board Statement: Not applicable.

Informed Consent Statement: Not applicable.

Data Availability Statement: The data presented in this study are available on request from the corresponding author. The data are not publicly available due to ethical restrictions.

Acknowledgments: We gratefully acknowledge the National Clean Air Program, and we extend our thanks to the National Knowledge Network. Part of this work was done while S.N. Tripathi was a fellow at the Institute for Advanced Sustainability Studies (IASS) in Potsdam, Germany. M. Rupakheti acknowledges the support provided by the IASS, which is funded by the German Federal Ministry for Education and Research (BMBF) and the Brandenburg Ministry for Science, Research, and Culture (MWFK). 
Conflicts of Interest: The authors declare no conflict of interest. The funders had no role in the design of the study; in the collection, analyses, or interpretation of data; in the writing of the manuscript; or in the decision to publish the results.

$\begin{array}{ll}\text { Abbreviations } & \\ \text { BC } & \text { Black carbon } \\ \text { BrC } & \text { Brown carbon } \\ \text { CMB } & \text { Chemical mass balance } \\ \text { DTT } & \text { Dithiothreitol } \\ \text { EC } & \text { Elemental carbon } \\ \text { HR-ToF-AMS } & \text { High-resolution time-of-flight aerosol mass spectrometer } \\ \text { HOA } & \text { Hydrocarbon-like organic aerosol } \\ \text { ICP-MS } & \text { Inductively coupled plasma mass spectroscopy } \\ \text { L-ToF-AMS } & \text { High-resolution long-time-of-flight aerosol mass spectrometer } \\ \text { LVOOA } & \text { Low-volatile oxygenated organic aerosol } \\ \text { ME } & \text { Multilinear engine } \\ \text { NCR } & \text { National Capital Region } \\ \text { NMOG } & \text { Nonmethane organic gases } \\ \text { NR } & \text { Nonrefractory } \\ \text { OC } & \text { Organic carbon } \\ \text { OA } & \text { Organic aerosol } \\ \text { OM/OC } & \text { Organic matter to organic carbon ratio } \\ \text { OP } & \text { Oxidative potential } \\ \text { PAN } & \text { Peroxyacetyl nitrate } \\ \text { PM } & \text { Particulate matter } \\ \text { PMF } & \text { Positive matrix factorization } \\ \text { PBL } & \text { Planetary boundary layer } \\ \text { PTR-ToF-MS } & \text { Proton-transfer-reaction time-of-flight mass spectrometer } \\ \text { POA } & \text { Primary organic aerosol } \\ \text { ROS } & \text { Reactive oxygen species } \\ \text { SDD } & \text { Silicon drift detector } \\ \text { SoFi } & \text { Source Finder } \\ \text { SOA } & \text { Secondary organic aerosol } \\ \text { SFC } & \text { Solid fuel combustion } \\ \text { SVOOA } & \text { Semivolatile oxygenated organic aerosol } \\ \text { ToF-ACSM } & \text { Time-of-flight aerosol chemical speciation monitor } \\ \text { TOC } & \text { Total organic carbon } \\ \text { VOCs } & \text { Volatile organic compounds } \\ \text { WS-BrC } & \text { Water-soluble brown carbon } \\ \text { XRF } & \text { X-rayorescence } \\ & \end{array}$

\section{References}

1. Singh, V.; Singh, S.; Biswal, A. Exceedances and trends of particulate matter $\left(\mathrm{PM}_{2.5}\right)$ in five Indian megacities. Sci. Total Environ. 2021, 750, 141461. [CrossRef] [PubMed]

2. Pant, P.; Shukla, A.; Kohl, S.D.; Chow, J.C.; Watson, J.; Harrison, R.M. Characterization of ambient PM $_{2.5}$ at a pollution hotspot in New Delhi, India and inference of sources. Atmos. Environ. 2015, 109, 178-189. [CrossRef]

3. Tiwari, S.; Thomas, A.; Rao, P.; Chate, D.; Soni, V.; Singh, S.; Ghude, S.; Singh, D.; Hopke, P.K. Pollution concentrations in Delhi India during winter 2015-2016: A case study of an odd-even vehicle strategy. Atmos. Pollut. Res. 2018, 9, 1137-1145. [CrossRef]

4. Balakrishnan, K.; Dey, S.; Gupta, T.; Dhaliwal, R.S.; Brauer, M.; Cohen, A.J.; Stanaway, J.D.; Beig, G.; Joshi, T.K.; Aggarwal, A.N.; et al. The Impact of Air Pollution on Deaths, Disease Burden, and Life Expectancy across the States of India: The Global Burden of Disease Study 2017. Lancet Planet. Health 2019, 3, 26-39. [CrossRef]

5. Li, H.; Xu, X.-L.; Dai, D.-W.; Huang, Z.-Y.; Ma, Z.; Guan, Y.-J. Air pollution and temperature are associated with increased COVID-19 incidence: A time series study. Int. J. Infect. Dis. 2020, 97, 278-282. [CrossRef]

6. Lolli, S.; Chen, Y.-C.; Wang, S.-H.; Vivone, G. Impact of meteorological conditions and air pollution on COVID-19 pandemic transmission in Italy. Sci. Rep. 2020, 10, 16213. [CrossRef]

7. Srivastava, A.; Gupta, S.; Jain, V. Winter-time size distribution and source apportionment of total suspended particulate matter and associated metals in Delhi. Atmos. Res. 2009, 92, 88-99. [CrossRef] 
8. Tiwari, S.; Srivastava, A.; Chate, D.; Safai, P.; Bisht, D.; Beig, G. Impacts of the high loadings of primary and secondary aerosols on light extinction at Delhi during wintertime. Atmos. Environ. 2014, 92, 60-68. [CrossRef]

9. Sharma, S.K.; Mandal, T.K.; Jain, S.; Saraswati; Sharma, A.; Saxena, M. Source Apportionment of PM 2.5 in Delhi, India Using PMF Model. Bull. Environ. Contam. Toxicol. 2016, 97, 286-293. [CrossRef]

10. Lalchandani, V.; Kumar, V.; Tobler, A.; Thamban, N.M.; Mishra, S.; Slowik, J.G.; Bhattu, D.; Rai, P.; Satish, R.; Ganguly, D.; et al. Real-time characterization and source apportionment of fine particulate matter in the Delhi megacity area during late winter. Sci. Total Environ. 2021, 770, 145324. [CrossRef] [PubMed]

11. Tobler, A.; Bhattu, D.; Canonaco, F.; Lalchandani, V.; Shukla, A.; Thamban, N.M.; Mishra, S.; Srivastava, A.K.; Bisht, D.S.; Tiwari, S.; et al. Chemical characterization of $\mathrm{PM}_{2.5}$ and source apportionment of organic aerosol in New Delhi, India. Sci. Total Environ. 2020, 745, 140924. [CrossRef] [PubMed]

12. Rai, P.; Furger, M.; El Haddad, I.; Kumar, V.; Wang, L.; Singh, A.; Dixit, K.; Bhattu, D.; Petit, J.-E.; Ganguly, D.; et al. Real-time measurement and source apportionment of elements in Delhi's atmosphere. Sci. Total Environ. 2020, 742, 140332. [CrossRef]

13. Wang, L.; Slowik, J.G.; Tripathi, N.; Bhattu, D.; Rai, P.; Kumar, V.; Vats, P.; Satish, R.; Baltensperger, U.; Ganguly, D.; et al. Source characterization of volatile organic compounds measured by PTR-ToF-MS in Delhi, India. Atmos. Chem. Phys. 2020, 20, 9753-9770. [CrossRef]

14. Bhowmik, H.S.; Naresh, S.; Bhattu, D.; Rastogi, N.; Prévôt, A.S.; Tripathi, S.N. Temporal and spatial variability of carbonaceous species (EC; OC.; WSOC and SOA) in PM $_{2.5}$ aerosol over five sites of Indo-Gangetic Plain. Atmos. Pollut. Res. 2021, 12, 375-390. [CrossRef]

15. Singh, A.; Rastogi, N.; Kumar, V.; Slowik, J.G.; Satish, R.; Lalchandani, V.; Thamban, N.M.; Rai, P.; Bhattu, D.; Vats, P.; et al. Sources and characteristics of light-absorbing fine particulates over Delhi through the synergy of real-time optical and chemical measurements. Atmos. Environ. 2021, 252, 118338. [CrossRef]

16. Rastogi, N.; Satish, R.; Singh, A.; Kumar, V.; Thamban, N.; Lalchandani, V.; Shukla, A.; Vats, P.; Tripathi, S.; Ganguly, D.; et al. Diurnal variability in the spectral characteristics and sources of water-soluble brown carbon aerosols over Delhi. Sci. Total Environ. 2021, 794, 148589. [CrossRef] [PubMed]

17. Puthussery, J.V.; Singh, A.; Rai, P.; Bhattu, D.; Kumar, V.; Vats, P.; Furger, M.; Rastogi, N.; Slowik, J.G.; Ganguly, D.; et al. Real-Time Measurements of $\mathrm{PM}_{2.5}$ Oxidative Potential Using a Dithiothreitol Assay in Delhi, India. Environ. Sci. Technol. Lett. 2020, 7, 504-510. [CrossRef]

18. Fröhlich, R.; Cubison, M.J.; Slowik, J.G.; Bukowiecki, N.; Prévôt, A.S.H.; Baltensperger, U.; Schneider, J.; Kimmel, J.R.; Gonin, M.; Rohner, U.; et al. The ToF-ACSM: A portable aerosol chemical speciation monitor with TOFMS detection. Atmos. Meas. Technol. 2013, 6, 3225-3241. [CrossRef]

19. DeCarlo, P.F.; Kimmel, J.R.; Trimborn, A.; Northway, M.J.; Jayne, J.T.; Aiken, A.C.; Gonin, M.; Fuhrer, K.; Horvath, T.; Docherty, K.S.; et al. Field-Deployable, High-Resolution, Time-of-Flight Aerosol Mass Spectrometer. Anal. Chem. 2006, 78, 8281-8289. [CrossRef]

20. Jordan, A.; Haidacher, S.; Hanel, G.; Hartungen, E.; Märk, L.; Seehauser, H.; Schottkowsky, R.; Sulzer, P.; Märk, T. A high resolution and high sensitivity proton-transfer-reaction time-of-flight mass spectrometer (PTR-TOF-MS). Int. J. Mass Spectrom. 2009, 286, 122-128. [CrossRef]

21. Drinovec, L.; Močnik, G.; Zotter, P.; Prévôt, A.S.H.; Ruckstuhl, C.; Coz, E.; Rupakheti, M.; Sciare, J.; Müller, T.; Wiedensohler, A.; et al. The "dual-spot" Aethalometer: An improved measurement of aerosol black carbon with real-time loading compensation. Atmos. Meas. Technol. 2015, 8, 1965-1979. [CrossRef]

22. Thamban, N.M.; Tripathi, S.N.; Moosakutty, S.P.; Kuntamukkal, P.; Kanawade, V.P. Internally mixed black carbon in the IndoGangetic Plain and its effect on absorption enhancement. Atmos. Res. 2017, 197, 211-223. [CrossRef]

23. Stephens, M.; Turner, N.; Sandberg, J. Particle identification by laser-induced incandescence in a solid-state laser cavity. Appl. Opt. 2003, 42, 3726. [CrossRef] [PubMed]

24. Paatero, P.; Tapper, U. Positive matrix factorization: A non-negative factor model with optimal utilization of error estimates of data values. Environmetrics 1994, 5, 111-126. [CrossRef]

25. Canonaco, F.; Crippa, M.; Slowik, J.G.; Baltensperger, U.; Prévôt, A.S.H. SoFi, an IGOR-based interface for the efficient use of the generalized multilinear engine (ME-2) for the source apportionment: ME-2 application to aerosol mass spectrometer data. Atmos. Meas. Technol. 2013, 6, 3649-3661. [CrossRef]

26. Paatero, P.; Hopke, P.K. Rotational tools for factor analytic models. J. Chemom. 2009, 23, 91-100. [CrossRef]

27. Ulbrich, I.M.; Canagaratna, M.R.; Zhang, Q.; Worsnop, D.R.; Jimenez, J.L. Interpretation of organic components from Positive Matrix Factorization of aerosol mass spectrometric data. Atmos. Chem. Phys. Discuss. 2009, 9, 2891-2918. [CrossRef]

28. Canonaco, F.; Slowik, J.G.; Baltensperger, U.; Prévôt, A.S.H. Seasonal differences in oxygenated organic aerosol composition: Implications for emissions sources and factor analysis. Atmos. Chem. Phys. Discuss. 2015, 15, 6993-7002. [CrossRef]

29. Crippa, M.; Canonaco, F.; Lanz, V.A.; Äijälä, M.; Allan, J.D.; Carbone, S.; Capes, G.; Ceburnis, D.; Dall'Osto, M.; Day, D.A.; et al. Organic aerosol components derived from 25 AMS data sets across Europe using a consistent ME-2 based source apportionment approach. Atmos. Chem. Phys. Discuss. 2014, 14, 6159-6176. [CrossRef]

30. Anderson, T.L.; Charlson, R.J.; Winker, D.M.; Ogren, J.; Holmén, K. Mesoscale Variations of Tropospheric Aerosols*. J. Atmos. Sci. 2003, 60, 119-136. [CrossRef] 
31. Campbell, J.R.; Ge, C.; Wang, J.; Welton, E.J.; Bucholtz, A.; Hyer, E.; Reid, E.A.; Chew, B.N.; Liew, S.C.; Salinas, S.V.; et al. Applying Advanced Ground-Based Remote Sensing in the Southeast Asian Maritime Continent to Characterize Regional Proficiencies in Smoke Transport Modeling. J. Appl. Meteorol. Clim. 2016, 55, 3-22. [CrossRef]

32. Canagaratna, M.; Jayne, J.; Jimenez, J.; Allan, J.; Alfarra, M.; Zhang, Q.; Onasch, T.; Drewnick, F.; Coe, H.; Middlebrook, A.; et al. Chemical and microphysical characterization of ambient aerosols with the aerodyne aerosol mass spectrometer. Mass Spectrom. Rev. 2007, 26, 185-222. [CrossRef]

33. Ng, N.L.; Canagaratna, M.R.; Zhang, Q.; Jimenez, J.L.; Tian, J.; Ulbrich, I.M.; Kroll, J.H.; Docherty, K.S.; Chhabra, P.S.; Bahreini, R.; et al. Organic aerosol components observed in Northern Hemispheric datasets from Aerosol Mass Spectrometry. Atmos. Chem. Phys. 2010, 10, 4625-4641. [CrossRef]

34. Kirchstetter, T.W.; Novakov, T.; Hobbs, P.V. Evidence that the spectral dependence of light absorption by aerosols is affected by organic carbon. J. Geophys. Res. Atmos. 2004, 109, 1-12. [CrossRef]

35. Singh, A.; Rastogi, N.; Patel, A.; Satish, R.V.; Singh, D. Size-segregated characteristics of carbonaceous aerosols over the north western Indo-Gangetic Plain: Year-round temporal behavior. Aerosol. Air Qual. Res. 2016, 16, 1615-1624. [CrossRef]

36. Ramachandran, S.; Rupakheti, M.; Lawrence, M.G. Black carbon dominates the aerosol absorption over the Indo-Gangetic Plain and the Himalayan foothills. Environ. Int. 2020, 142, 105814. [CrossRef]

37. de Gouw, J.; Warneke, C. Measurements of volatile organic compounds in the earth's atmosphere using proton-transfer-reaction mass spectrometry. Mass Spectrom. Rev. 2007, 26, 223-257. [CrossRef] [PubMed]

38. Zhang, R.; Jing, J.; Tao, J.; Hsu, S.-C.; Wang, G.; Cao, J.; Lee, C.S.L.; Zhu, L.; Chen, Z.; Zhao, Y.; et al. Chemical characterization and source apportionment of $\mathrm{PM}_{2.5}$ in Beijing: Seasonal perspective. Atmos. Chem. Phys. Discuss. 2013, 13, 7053-7074. [CrossRef]

39. Yu, L.D.; Wang, G.F.; Zhang, R.J.; Zhang, L.M.; Song, Y.; Wu, B.B.; Li, X.F.; An, K.; Chu, J.H. Characterization an source apportionment of $\mathrm{PM}_{2.5}$ in an urban environment in Beijing. Aerosol. Air Qual. Res. 2013, 13, 574-583. [CrossRef]

40. Liu, B.; Li, T.; Yang, J.; Wu, J.; Wang, J.; Gao, J.; Bi, X.; Feng, Y.; Zhang, Y.; Yang, H. Source apportionment and a novel approach of estimating regional contributions to ambient $\mathrm{PM}_{2.5}$ in Haikou, China. Environ. Pollut. 2017, 223, 334-345. [CrossRef] [PubMed]

41. Heo, J.-B.; Hopke, P.K.; Yi, S.-M. Source apportionment of $\mathrm{PM}_{2.5}$ in Seoul, Korea. Atmos. Chem. Phys. Discuss. 2009, 9, 4957-4971. [CrossRef]

42. Jeong, J.H.; Shon, Z.H.; Kang, M.; Song, S.K.; Kim, Y.K.; Park, J.; Kim, H. Comparison of source apportionment of PM 2.5 using receptor models in the main hub port city of East Asia: Busan. Atmos. Environ. 2017, 148, 115-127. [CrossRef]

43. Yau, P.S.; Lee, S.C.; Cheng, Y.; Huang, Y.; Lai, S.C.; Xu, X.H. Contribution of ship emissions to the fine particulate in the community near an internationalport in Hong Kong. Atmos. Res. 2013, 124, 61-72. [CrossRef]

44. Cheng, Y.; Lee, S.; Gu, Z.; Ho, K.; Zhang, Y.; Huang, Y.; Chowa, J.C.; Watson, J.G.; Cao, J.; Zhang, R. PM 2.5 and PM10-2.5 chemical composition and source apportionment near a Hong Kong roadway. Particuology 2014, 18, 96-104. [CrossRef]

45. Wimolwattanapun, W.; Hopke, P.K.; Pongkiatkul, P. Source apportionment and potential source locations of $\mathrm{PM}_{2.5}$ and $\mathrm{PM}_{2.5}-10$ at residential sites in metropolitan Bangkok. Atmos. Pollut. Res. 2011, 2, 172-181. [CrossRef]

46. Islam, M.; Jayarathne, T.; Simpson, I.J.; Werden, B.; Maben, J.; Gilbert, A.; Praveen, P.S.; Adhikari, S.; Panday, A.K.; Rupakheti, M.; et al. Ambient air quality in the Kath-mandu Valley, Nepal during the pre-monsoon: Concentrations and sources of particulate matter and trace gases. Atmos. Chem. Phys. 2020, 20, 2927-2951. [CrossRef]

47. Bandyopadhyay, A. Neurological Disorders from Ambient (Urban) Air Pollution Emphasizing UFPM and PM 2.5 . Curr. Pollut. Rep. 2016, 2, 203-211. [CrossRef]

48. Genc, S.; Zadeoglulari, Z.; Fuss, S.H.; Genc, K. The adverse effects of air pollution on the nervous system. J. Toxicol. 2012, 2012, 782462. [CrossRef] 